Original paper

\title{
Unidirectional solidification textures and garnet layering in Y-enriched garnet-bearing aplite-pegmatites in the Cadomian Brno Batholith, Czech Republic
}

\author{
Sven HÖNIG*, Jaromír LEICHMANN, Milan NOVÁK \\ Department of Geological Sciences, Masaryk University, Kotlářská 2, 61137 Brno, Czech Republic; honig@mail.muni.cz \\ * Corresponding author
}

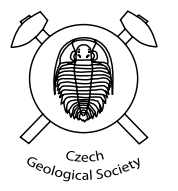

Layered, garnet-bearing aplite-pegmatite dykes of the Hlína granitic suite, $\sim 2$ to $50 \mathrm{~m}$ thick and up to $200 \mathrm{~m}$ long with general NW-SE orientation and dip $40-80^{\circ}$ to NE or SW, cut granodiorites to granites at the SW part of the Brno Batholith, Brunovistulicum, Czech Republic. Aplite-pegmatite bodies are characterized by alternation of two main textural units: (i) fine-grained aplite unit with garnet stripes and (ii) coarse-grained pegmatite unit with oriented Qtz, Plg and Kfs comb-like crystals known as Unidirectional Solidification Textures (UST). Both units developed in zones with the thickness varying from several $\mathrm{cm}$ to $\sim 1-2 \mathrm{~m}$ for aplite unit, and $\sim 10 \mathrm{~cm}$ for the UST unit. All rock types are characterized by high contents of $\mathrm{SiO}_{2}$ (74.6-75.7 wt. \%), $\mathrm{K}_{2} \mathrm{O}$ (4.61-4.94 wt. \%), $\mathrm{Na}_{2} \mathrm{O}$ (3.82-4.21 wt. \%), moderate concentration of $\mathrm{CaO}\left(0.94-1.11\right.$ wt. \%), and low to very low concentrations of $\mathrm{Fe}_{2} \mathrm{O}_{3}{ }^{\mathrm{T}}(0.62-0.93$ wt. \%), $\mathrm{MgO}(0.02-0.03$ wt. \%), and $\mathrm{TiO}_{2}(\leq 0.03$ wt. \%). Low $\mathrm{K} / \mathrm{Rb}(212-241)$ and high $\mathrm{K} / \mathrm{Ba}$ ratios (1034-2303) with deep Eu anomaly indicate high degree of fractionation. Both textural units consist of perthitic microcline, plagioclase $\mathrm{An}_{15-8}$ and quartz. Total amount of accessory minerals is typically very low, commonly $<\sim 1$ vol. \% in aplite unit, and in the UST unit they are almost absent. Accessory minerals include relatively common Y-rich garnet $\operatorname{Sps}_{42-38} \operatorname{Alm}_{32-28} \operatorname{And}_{15-7} \operatorname{Grs}_{21-15} \operatorname{Prp}_{2-1}(1.10$ wt. \% $\mathrm{Y}_{2} \mathrm{O}_{3}, 0.53 \mathrm{wt} . \% \mathrm{Yb}_{2} \mathrm{O}_{3}$ and $0.20 \mathrm{wt} . \% \mathrm{Er}_{2} \mathrm{O}_{3}$ ) with oscillatory and sector zoning. Other minerals closely associated with garnet are extremely rare: magnetite, chloritized biotite, muscovite, Ta-rich titanite I, Al, F-rich titanite II, and ilmenite. Primary zircon, xenotime-(Y), monazite-(Nd), fersmite, ferrocolumbite, REE, Y-rich pyrochlore are strongly altered. Geochemical and mineralogical features of the Hlína aplite-pegmatites are characterized by (i) subaluminous chemistry with $\mathrm{Nb}>>$ Ta and HREE > LREE, A-type (NYF) affinity, indicated by elevated concentrations of Y, REE (especially HREE), Zr, U, Th, Nb, and Ta, (ii) occurrence of specific accessory minerals including Y-rich garnet, and (iii) a remarkable, almost complete absence of micas and other minerals with volatiles ( $\mathrm{B}, \mathrm{F}, \mathrm{P}$ and also $\mathrm{H}_{2} \mathrm{O}$ ). The studied suite differs from all other granitic rocks with UST described to date, which are typically characterized by volatile-bearing minerals and peraluminous signatures. Magmatic layering involving garnet is explained by formation of a boundary chemical layer bordering the surface of the coarse-grained UST unit.

Keywords: Unidirectional Solidification Texture, magmatic layering, garnet, yttrium, aplite-pegmatite, Brno Batholith Received: 21 December 2009; accepted: 14 June 2010; handling editor: P. Nabelek

\section{Introduction}

Granitic pegmatites are characterized by high variability in their internal structure, mineralogy and, in particular, textures. These textures include fine- to coarse-grained graphic intergrowths of quartz plus feldspars, giant crystals of blocky K-feldspars and spodumene, up to several meters in size, huge quartz core, and fine-grained aplitic units. Variable albite- and/or lepidolite-rich replacement units, as well as repetitive layered textures such as simple layering with randomly oriented crystals or with minerals aligned parallel to the layers, are also present (e.g., London 2008). Rockhold et al. (1987) described such magmatic layering in the B-rich granite-pegmatite complex at the Calamity Peak, South Dakota, USA, where repetitive layered aplite and coarse-grained pegmatite occur in an about $400 \mathrm{~m}$ thick body. Duke et al. (1992) revealed at the same locality that upper parts (= pegmatite zones) of the layered aplite-pegmatite bodies are usually K-rich, whereas lower parts (= aplite zones) are enriched in $\mathrm{Na}$ and similar textural relations are known from many granitic pegmatites and aplites worldwide (London 2008). The bulk chemical composition of the layered zones is usually similar to that of the whole rock (Zaraisky et al. 1997).

Unidirectional solidification textures (UST) were recognized as a specific type of the magmatic layering. This non-genetic term describes the morphological features of layers with crystals oriented perpendicular to, or with high angle to, the strike of a layer. It was used for the first time by Shannon et al. (1982) for textures observed in subvolcanic granitic bodies at the Henderson Mine, Empire, Colorado; however, older Russian texts published by Kormilitsyn and Manuilova (1957) also described identi- 
cal textural features in the Transbaykal region. Similar textures were recently found in many aplite-pegmatites as well (e.g., London 1992; Breiter et al. 2005). Typical morphological features of UST are comb-like or crenulate shape of the crystals oriented perpendicularly to the layer. These crystals are present in layers and multilayered sequences, with textures indicative of mineral growth in one direction from a solid substrate.

The Brno Batholith, Czech Republic, a Cadomian magmatic complex of dominant amphibole-biotite and biotite granitoids, only sporadically contains pegmatites or other more evolved leucocratic granitic rocks (Staněk 1982). They exhibit an $A$-type affinity and are common only in the southern part of the Western Granitoid Complex (Leichmann and Höck 2008). This paper focuses on these aplite-pegmatites, including their internal structure, mineral composition, and nature/genesis of UST in particular.

\section{Geological setting of the Brno Batholith}

The Brno Batholith is the most extensive part of the Brunovistulicum (Dudek 1980) or the Brunovistulian Complex (Jelínek and Dudek 1993) on the Czech territory. The Brunovistulicum is built by dominant plutonic rocks (granodiorites, granites, quartz diorites), metamorphic rocks (migmatites, metadiorites, calc-silicate rocks) and their sedimentary cover (Devonian and Lower Carboniferous sediments, and some Tertiary and Quaternary sediments). The eastern part of the Brunovistulicum, which was not reactivated during the Variscan orogeny, acted as a stable foreland for the Variscan and the Alpine fold belts. In the west, the Moravicum was thrusted onto non-mobilized part of the Brunovistulicum, and in turn was concealed under the Variscan Moldanubian nappes. In the east, the Brunovistulicum is covered by the Carpathian nappes along with its Devonian to Lower Carboniferous sedimentary cover.

Three distinct internal subunits were recognized in the Brno Batholith (Fig. 1a), each separated by sharp tectonic boundaries: Central Metabasite Zone, Western Granitoid Complex and Eastern Granitoid Complex. The Central Metabasite Zone (Štelcl and Weiss 1986) also known as the Central Basic Belt (Finger et al. 2000a) is divided into two distinctive sequences - plutonic, consisting of ultramafic rocks, amphibole-bearing diorites, gabbros and trondhjemites (Leichmann 1994), and volcanic, composed of basalts and bimodal association of dolerites and rhyolites. The central part is cut by granitoids of both granitoid complexes. The primary intrusion contacts between Central Metabasite Zone and adjacent granitoids were strongly tectonically overprinted during the Variscan orogeny (Hanžl and Melichar 1997).
The Eastern Granitoid Complex is rather homogeneous, consisting of amphibole to amphibole-biotite quartz diorites and granodiorites; rare trondhjemitic rocks are present as well. All the rock types are characterized by low contents of $\mathrm{K}_{2} \mathrm{O}$ and $\mathrm{Rb}$, but granodiorites are rich in $\mathrm{MgO}, \mathrm{Na}_{2} \mathrm{O}, \mathrm{CaO}$ and $\mathrm{Sr}$ (Hanžl 1994). The geochemical data show an overall affinity to $I$-type granitoids of a primitive volcanic-arc (Leichmann 1996). The Western Granitoid Complex is built up by granites, granodiorites, quartz diorites and diorites which intruded high- to medium-grade gneisses, amphibolites and calc-silicate rocks. The earlier classification, based chiefly on petrographic descriptions, divided this granitoid complex into eight (Štelcl and Weiss 1986) or seven (Mittrenga and Rejl 1993) granitoid types (Fig. 1). The recent study based on the geochemical, structural and mineralogical data distinguished three distinctive granitic suites only (Leichmann and Höck 2008). Two of them (Tetčice and Réna suites) are represented by evolved rocks of an active continental margin with affinities to $S$ - and $I$-type granites. The third suite (Hlína suite), composed by felsic, garnet-bearing, aplite-pegmatite intrusions, was interpreted as $A$-type granites (Leichmann et al. 1999).

Post-tectonic subvolcanic dykes intruded all parts of the Brno Batholith. The age of rhyolites crosscutting metabasalts of the Central Metabasite Zone (determined by $\mathrm{Pb}-\mathrm{Pb}$ evaporation of zircon at $725 \pm 15 \mathrm{Ma}$; Finger et al. 2000a) indicates a minimum age of this ophiolite complex. Some geochronological data published from the Eastern and Western granitoid complexes are much younger. Dallmeyer et al. (1994; see also Fritz et al. 1996) determined an ${ }^{40} \mathrm{Ar} /{ }^{39} \mathrm{Ar}$ age of $596.1 \pm 2.1 \mathrm{Ma}$ on amphibole from the Eastern Granitoid Complex. In the Western Granitoid Complex, ${ }^{40} \mathrm{Ar} /{ }^{39} \mathrm{Ar}$ amphibole dating yielded $586.9 \pm 0.5 \mathrm{Ma}$ (Dallmeyer et al. 1994) and conventional $\mathrm{U}-\mathrm{Pb}$ zircon dating $584 \pm 5 \mathrm{Ma}$ (van Breemen et al. 1982).

\section{Granites of the Western Granitoid Complex}

\subsection{Tetčice suite}

Three principal magmatic suites - Réna, Tetčice, and Hlína - have been recognized in the Western Granitoid Complex (Fig. 1b, see Leichmann and Höck 2008). The northernmost Tetčice suite is formed by (i) grey, finegrained, biotite granite, (ii) reddish, coarse-grained, biotite granite, and (iii) greenish grey, medium- to coarse-grained, biotite-amphibole diorite usually in the form of rounded enclaves, up to $2 \mathrm{~m}$ in size, present in both granite types. There is a transition between the two granite facies; the contact with the Central Metabasite 


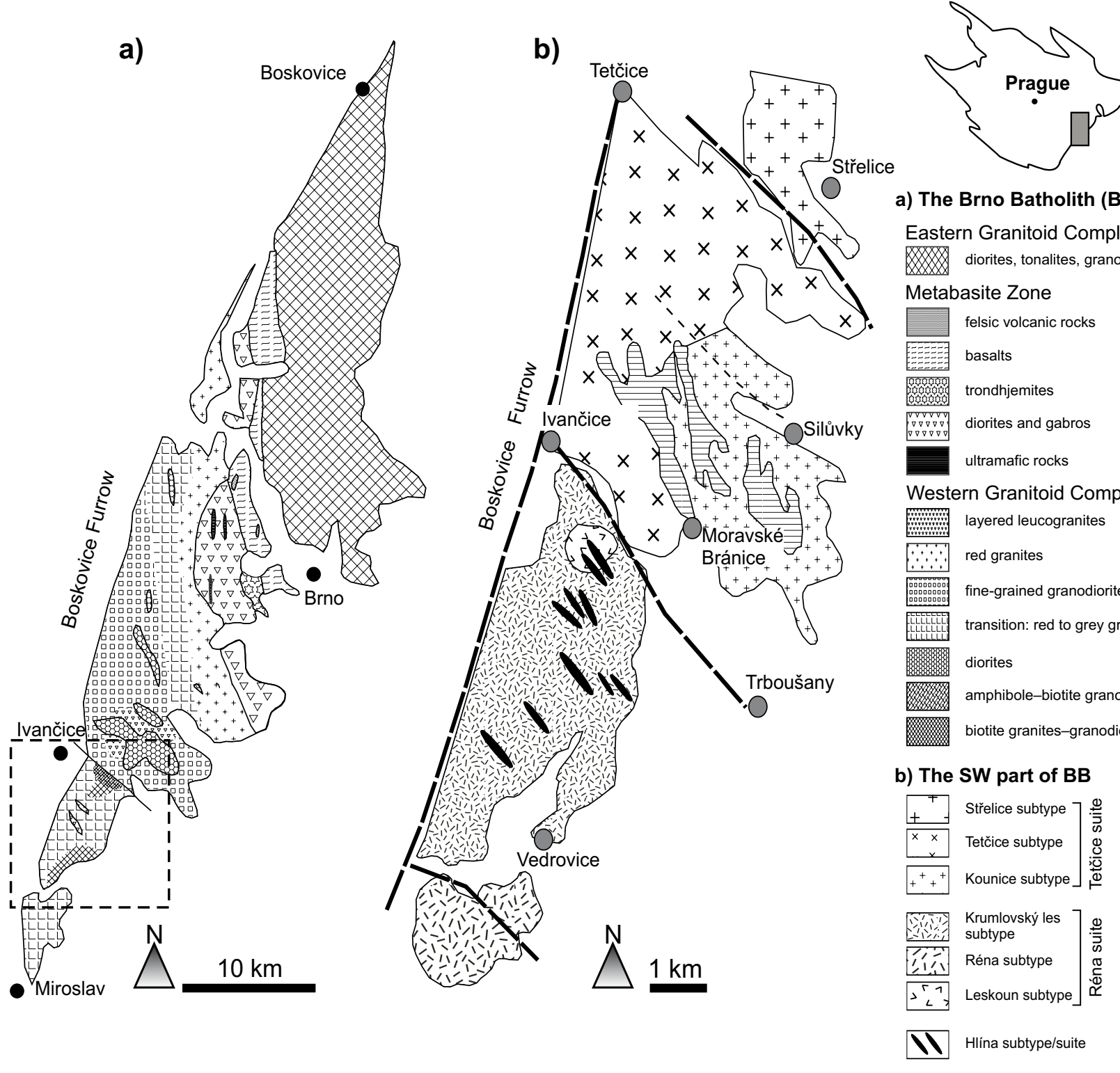

Fig. 1a - Simplified geological map of the Brno Batholith (modified from Leichmann and Höck 2008); the outlined square area is enlarged in Fig. 1b. b - Simplified sketch of the SW part of the Brno Batholith, modified from Mittrenga et al. (1976). According to a new scheme (Leichmann and Höck 2008) the Střelice, Kounice and Tetčice subtypes are now classified as the Tetčice suite, the Krumlovský les, Réna and Leskoun subtypes belong to the Réna suite and the Hlína subtype is now classified as the Hlína suite. Inset shows position of the studied region within the Bohemian Massif.

Zone to the northeast is tectonic. In the southwest they are surrounded by reddish, coarse-grained biotite granites. Contact between both types of granitoids and diorite is usually transitional, but occasionally sharp.

The granitoids of Tetčice suite are very heterogeneous containing a wide spectrum of metasedimentary xenoliths and roof pendants (e.g., migmatites, gneisses, and calc-silicate rocks) varying from few centimeters to kilometers in size. Based on geochemical data and zircon crystals morphology, the Tetčice granitoids are $S$-type rocks. They are separated from the Réna suite by E-W-trending Ivančice-Trboušany Fault (Mittrenga et al.
1976; Leichmann 1996), which is marked on the surface by the Jihlava river valley. The steep gravimetric gradient, up to $\sim 20 \mathrm{mGal}$ (Skácelová and Weiss 1978), clearly separates relatively dense granitoids of the Tetčice suite from relatively light granitoids of the Réna suite further to the south.

\subsection{Réna suite}

The Réna suite is built by felsic $\left(\mathrm{SiO}_{2}>69\right.$ wt. \%), coarse-grained, amphibole-biotite granodiorites that evolved into biotite granites. Amphibole-rich, cumulate- 
like layers, up to $1 \mathrm{~m}$ thick, occur sporadically. The minerals in the granodiorite through granite include oscillatory-zoned, euhedral plagioclase $\left(\mathrm{An}_{40-6}, 36-55\right.$ vol. \%) which is often altered to sericite, anhedral quartz (23-29 vol. \%), euhedral to subhedral K-feldspar (10-26 vol. \%), biotite ( $0.5-8$ vol. \%) which is replaced by secondary chlorite (up to 10 vol. \%), and euhedral amphibole (up to 7 vol. \%). Titanite, zircon, and apatite are common accessories. Considerable degree of fractionation from granodiorites to granites is indicated by the decreasing $\mathrm{X}_{\mathrm{Mg}}$ in amphibole and gradual disappearance of this mineral, as well as lower contents of $\mathrm{V}, \mathrm{Cr}$ and $\mathrm{Ni}$ in the granites (Leichmann et al. 1999; Leichmann and Höck 2008). Given the zircons morphology and composition of the Réna granitoid suite, which is characterized by low HFSE contents (71-125 ppm Zr, 10-15 ppm Nb and $10-25 \mathrm{ppm} \mathrm{Y}$ ), moderate ASI of 1.1, and decreasing Mg/ Fe values, the Réna suite can be classified as a volcanicarc, $I$-type granitic association (see Leichmann and Höck 2008 for more details).

\subsection{Hlína suite}

The Hlína suite is represented by thick $(\leq 50 \mathrm{~m})$ irregular bodies and dykes of felsic, K-rich, fine- to coarsegrained, garnet-bearing aplites and aplite-pegmatites. They intruded granodiorites and granites of the Réna suite and, less frequently, granites exposed inside the Tetčice suite. Brecciation of aplitic rocks by rare fluorite veins has also been observed. Granitoids of this suite differ markedly from all $S$-type and $I$-type granites known from the Brunovistulicum and they were classified as $A$ type (Leichmann et al. 1999; Leichmann an Höck 2008). Detailed description of these rocks is given below.

\section{Analytical methods}

The textural relations and zoning in feldspars were studied by a cathodoluminescence device with hot cathode $\mathrm{HC}_{2}$-LM, Simon Neuser, Bochum, in the CL laboratory of Masaryk University. Analytical conditions were vacuum $0.01 \mathrm{mbar}$, accelerating voltage $14 \mathrm{kV}$ and beam density $10 \mathrm{~mA} / \mathrm{mm}^{2}$.

Mineral analyses were carried out by CAMECA SX100 electron microprobe in wavelength-dispersion mode at the Department of Geological Sciences, Masaryk University. Analytical conditions employed were $2 \mu \mathrm{m}$ beam diameter, $15 \mathrm{kV}$ acceleration potential and $40 \mathrm{nA}$ current. Standards for elements analyzed at $\mathrm{K}_{\alpha}$ lines were: $\mathrm{Si}, \mathrm{K}$ (sanidine), $\mathrm{Ti}$ (hornblende), $\mathrm{Al}$ (andalusite), $\mathrm{Fe}$ (andradite), $\mathrm{Mn}$ (rhodonite), $\mathrm{Mg}$ (augite), $\mathrm{Ca}$ (andradite), $\mathrm{Na}$ (albite), $\mathrm{Cr}$ (chromite), $\mathrm{F}$ (topaz) and $\mathrm{P}$ (apatite). For the $\mathrm{L}_{\alpha}$ lines these were: $\mathrm{Y}(\mathrm{YAG}), \mathrm{Yb}\left(\mathrm{YbP}_{5} \mathrm{O}_{14}\right)$,
Er (YErAg) and Zr (zircon). The analytical data were corrected using the PAP correction procedure (Pouchou and Pichoir 1985).

Major elements were determined at the Acme Chemical Laboratories Ltd, Vancouver, Canada, by using ICP-ES after fusion with lithium borate flux. Trace elements, including the REE, were analyzed by ICP-MS with additional lithium tetraborate fusion. See http:// www.acmelab.com for analytical details.

\section{Results}

\subsection{Geological position and internal structure of aplite-pegmatite bodies of the Hlína suite}

Dykes and lens-shaped bodies of the Hlína aplite-pegmatites and associated aplitic granites (not studied in detail in this work) cut granodiorites of the Réna suite and occur almost exclusively south of the Ivančice-Trboušany tectonic lineament (Fig. 1). The examined aplite-pegmatite bodies are $\sim 2$ to $50 \mathrm{~m}$ thick and up to $\sim 200 \mathrm{~m}$ long with a general NW-SE strike and dip $40-80^{\circ}$ to the northeast or the southwest. Sharp contacts of the aplite-pegmatite dykes and host granodiorites are only scarcely exposed and commonly strongly weathered. Reddish, weathered reaction zones, which are several meters wide, are locally developed along the contacts. Both aplite and pegmatite units were found in direct contact with host granitoids. In respect to the internal structures of the Hlína aplitepegmatite bodies, two main heterogeneous, texturally different, but coeval and geologically related intrusion types can be distinguished: (a) aplite-pegmatite dykes without any oriented structures, and (b) dykes with generally finegrained layered aplite units containing parallel alternating comb-like coarse-grained UST units. In the latter type, studied in detail in this paper, contacts of both (aplite and UST) units are typically sharp although gradual transitions were also observed. Thickness of the individual zones varies from several $\mathrm{cm}$ to $\sim 1-2 \mathrm{~m}$ for aplites and $\sim 10 \mathrm{~cm}$ for UST zones. The layered character of aplitic rocks is accented by parallel stripes of garnet grains.

\subsection{Textures and petrography of aplite- -pegmatite dykes}

Textural-paragenetic units composing the aplite-pegmatite bodies differ significantly in texture, grain size and mineral composition. They include the prevalent, finegrained aplite unit and the subordinate, coarse-grained UST unit developed chiefly at the locality Moravské Bránice that was studied in detail (Fig. 2). The pegmatite units (devoid of the UST), including coarse-grained 

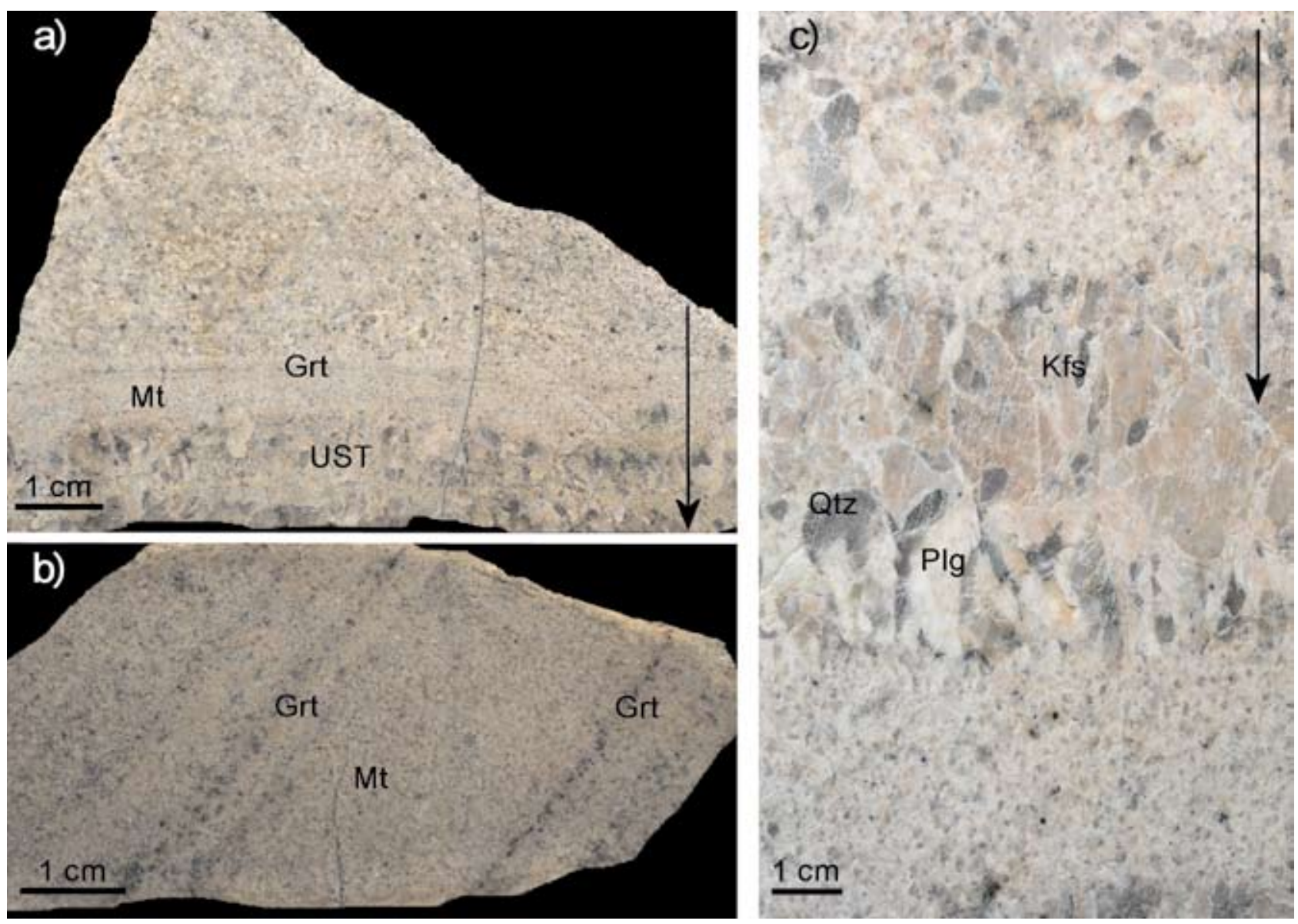

Fig. 2 Macrotextures of the aplite-pegmatite from Moravské Bránice. a - From top to bottom: fine-grained aplite unit, thin stripe/train of the garnets with associated magnetite, UST unit with downward pointing comb-like Plg, Kfs and Qtz. b - Aplite unit with several parallel garnet stripes and associated magnetite. c - UST unit with typical comb-shaped Plg, Qtz and Kfs alternating with fine-grained aplite unit. Arrow shows the inferred direction of crystallization.

pegmatite zones with locally developed graphic units and blocky quartz, are typical also of the other aplitepegmatite localities in this region.

Aplite units are pinkish, medium- to mostly finegrained ( 0.5 to $2 \mathrm{~mm}$ grain size) and with typical aplitic (panallotriomorphic) texture composed of plagioclase (38-45 vol. \%), K-feldspar (23-30 vol. \%) and quartz (20-30 vol. \%). Total amount of accessory minerals (e.g., garnet and magnetite) is very low, commonly $<\sim 1$ vol. \%. Plagioclase $\mathrm{An}_{15-8}$ is simply zoned with more calcic core and a myrmekitic texture commonly developed on the contact with K-feldspar. Subhedral plagioclase is replaced by K-feldspar or quartz, late alterations include formation of secondary muscovite and prehnite. Light pink subhedral crystals of K-feldspar show two or more crosscutting perthitic systems. Anhedral grains of quartz $(<0.3 \mathrm{~mm})$ are randomly distributed and exhibit undulose extinction. The accessory minerals are dominated by Y-rich spessartine-almandine with oscillatory and sector zoning. The other minerals - chloritized biotite, magne- tite, titanite, zircon, xenotime-(Y), and their alteration products, as well as several $\mathrm{Nb}-\mathrm{Ta}-\mathrm{Ti}$ oxide minerals - are very rare.

Garnet is present in two distinct textural and morphological forms (Fig. 3). The first type includes numerous small grains $(<0.5 \mathrm{~mm})$ always arranged into long stripes (from several decimeters to several meters long), where the individual garnet crystals are almost in direct contact. (A similar texture from Newer Caledonian Cairngorm granite, Scotland has been called the train texture by Macleod 1992). These stripes are strictly parallel to the strike of the aplite unit in the aplite-pegmatite body and locally alternate with similar, but less abundant, associated stripes of magnetite grains. The second type of garnet is represented by solitary phenocrysts $(0.5$ to $4 \mathrm{~mm}$ in diameter) enclosed in fine-grained aplite matrix. They show glomerophyric (atoll shape) concentric structure, where small flakes of muscovite or tiny grains of $\mathrm{K}$-feldspar are enclosed in garnet cores. Most accessory minerals occur close to garnet grains. 

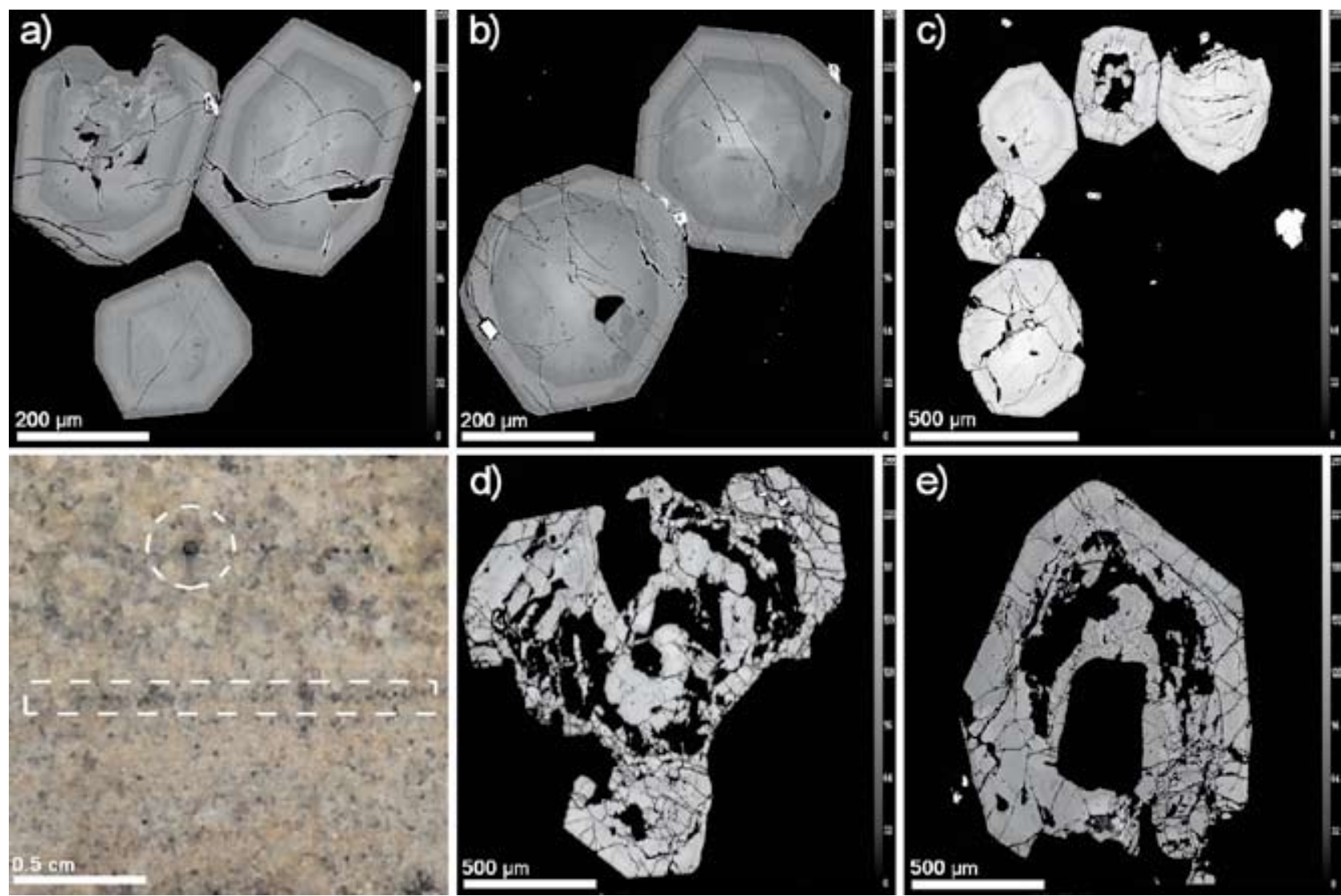

Fig. 3 The back-scattered electron (BSE) images for two distinct morphological forms of the garnet. Upper row images (a-c) come from a garnet stripe, highlighted by dashed rectangle area on the hand specimen photograph also shown. Typical is a complex inner fabric (with sector and oscillatory zones). View c represents individual garnet crystals arranged in a train texture. d-e Solitary glomerophyric garnet, highlighted by dashed circle on a hand specimen, that occurs in fine-grained aplitic matrix. Zoning is less pronounced and characteristic are many inclusions of muscovite flakes and tiny $\mathrm{Kfs}$ grains.

Coarse-grained UST units with the grain size of $1-10 \mathrm{~cm}$ are developed almost exclusively at the locality Moravské Bránice where the thicknesses of the individual layers are $\sim 3-10 \mathrm{~cm}$. Idealized cross-section through the examined dyke is given in Fig. 4. At the other localities, a coarse-grained pegmatite unit occurs instead, or evidently predominates. Major minerals include K-feldspar, plagioclase $\left(\mathrm{An}_{15-10}\right)$ and quartz; accessory minerals are extremely rare. Large crystals of K-feldspar and plagioclase are up to 3 centimeters long, subhedral to euhedral with typical comb-like textures, whereby the individual crystals have the same orientation as the neighboring ones. Comb-like quartz crystals also show the same feature. They also are arranged perpendicularly to the strike of the pegmatite unit. The tops of elongated crystals are always growing into the fine-grained aplite unit with sharp boundaries, in contrast to the bottom sides where transitional boundaries occur (Fig. 2c). Quartz grains $(2-5 \mathrm{~cm}$ long) are rarely rimmed by plagioclase-quartz myrmekites.
At neighboring localities the dykes also consist of a coarse-grained pegmatite unit, differing significantly from the aplite unit in grain size $(1-25 \mathrm{~cm})$, texture and mineral composition, but resembling the coarse-grained UST unit in grain size, mineral assemblages and scarcity of accessory minerals. Major minerals include K-feldspar, plagioclase $\left(\mathrm{An}_{15-10}\right)$ and quartz. Only locally are developed masses of blocky quartz, up to $25 \mathrm{~cm}$ across, within coarse-grained pegmatite units. They fill space among large euhedral to subhedral crystals of reddish K-feldspar and subhedral crystals and aggregates of white plagioclase. The blocky quartz resembles quartz cores of ordinary granitic pegmatites, but the quartz is closely related to the zones of coarse-grained pegmatite units, which are alternating with aplite zones. Accessory minerals are very rare in this pegmatite unit. A graphic unit as a part of a coarse-grained pegmatite unit was found only at some aplite-pegmatite bodies as an irregular mass, up to $50 \mathrm{~cm}$ in size. Both K-feldspar + quartz and plagioclase + quartz intergrowths are closely associated and size of 


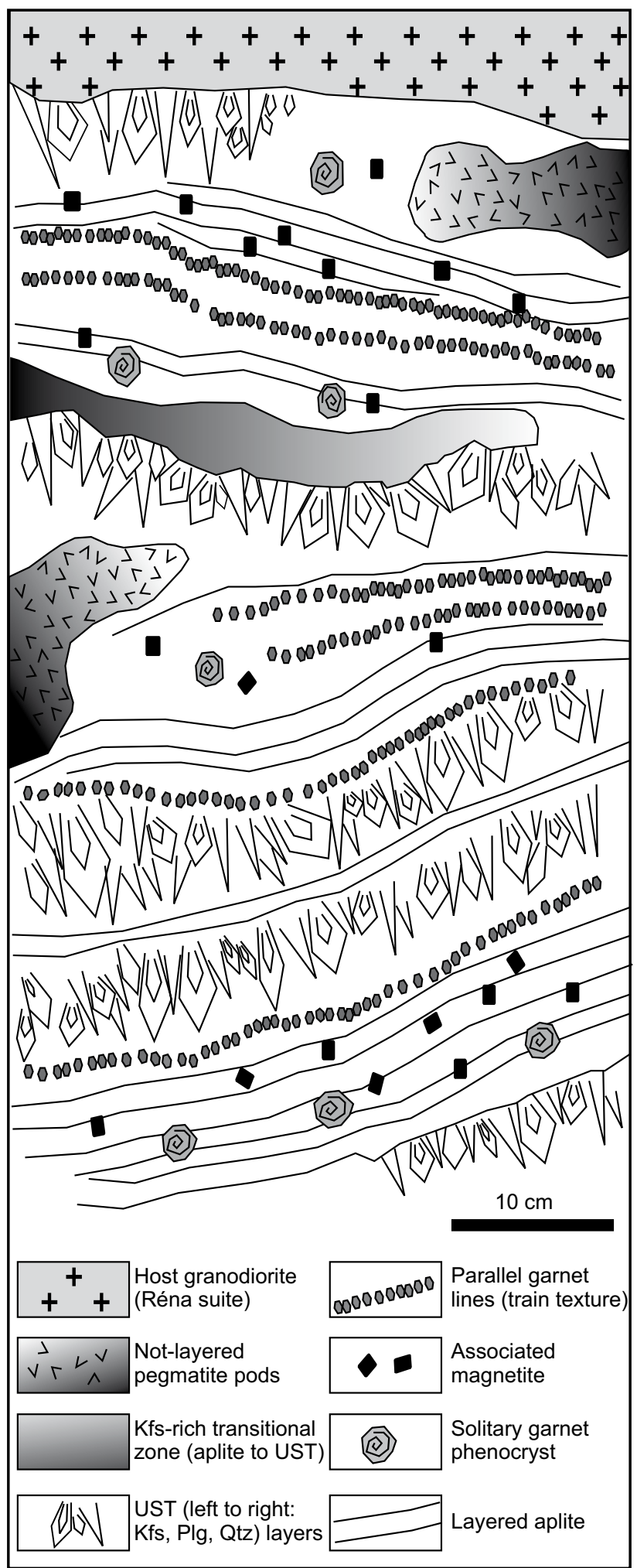

Fig. 4 Schematic vertical section through the best exposed Hlína layered intrusion. Individual layers are not to scale. Direction of crystallization is from the upper contact downward. The upper contact with host Réna granodiorite appears to be sharp, whereas the opposite contact has not been found. Typical thickness of individual layers varies from 0.1 to $0.5 \mathrm{~m}$ for aplites and from 0.2 to $10 \mathrm{~cm}$ for the UST units. the individual quartz grains is highly variable. The most abundant intergrowths of K-feldspar and quartz are up to $15 \mathrm{~cm}$ across, whereas graphic intergrowths of plagioclase and quartz (up to $6 \mathrm{~cm}$ across) are less common.

\subsection{Cathodoluminescence study of textures in feldspars}

Zoned feldspars within the fine-grained aplite unit are very common (Fig. 5a-b). Subhedral grains of plagioclase with light to dark green color usually have multiple oscillatory zones (core $-\mathrm{An}_{15}$, rim $-\mathrm{An}_{8}$ ) and are frequently rimmed by markedly well developed granophyric textures on borders with neighboring K-feldspars. Subhedral grains of K-feldspars, lacking perthites, show several types of well-developed zoning. The zoning is marked by variable intensity of blue color with hourglass sector zoning as well as light blue sector zones dissolved on K-feldspar's corroded rims.

Feldspars in the coarse-grained UST unit also display zoned textures (Fig. 5c-d). Comb-like K-feldspar crystals contain commonly perthites oriented in many directions in their central parts and no granophyric textures on contact with neighboring minerals. The comb-like crystals show light-blue sector luminescence with sharply jagged rims in their middle parts; the outer parts of the crystals are dark blue without any zoning. These outer parts are characterized by dark-blue areas without zoning but subsidiary oscillatory zoning appears.

In both UST and fine-grained Kfs, no differences in chemical composition, which could be responsible for CL zoning, were observed on the electron microprobe. The concentrations of all these elements (e.g. Marshall 1988) were below their respective detection limits.

\subsection{Whole-rock chemistry}

Three main rock types in the aplite-pegmatite bodies at the locality Moravské Bránice - aplite unit without stripes of garnet (only rare atoll garnets are present), aplite unit with garnet stripes and coarse-grained UST unit, were studied in detail and the representative chemical analyses are given in Tab. 1. All aplite-pegmatites of the Hlína suite have a felsic character documented by high contents of $\mathrm{SiO}_{2}$ (74.6-75.7 wt. \%), $\mathrm{K}_{2} \mathrm{O}$ (4.61-4.94 wt. \%), $\mathrm{Na}_{2} \mathrm{O}(3.82-4.21$ wt. \%), moderate concentrations of $\mathrm{CaO}(0.94-1.11$ wt. \%), and low to very low concentrations of $\mathrm{Fe}_{2} \mathrm{O}_{3}{ }^{\mathrm{T}}(0.62-0.93$ wt. \%), MgO (0.02-0.03 wt. $\%)$ and $\mathrm{TiO}_{2}(\leq 0.03$ wt. \%). Slightly elevated concentrations of $\mathrm{Rb}(170-182 \mathrm{ppm})$ and $\mathrm{MnO}(0.12-0.32$ wt. \%) are positively correlated with $\mathrm{Y}$ and HREE concentrations. Low $\mathrm{K} / \mathrm{Rb}$ (212-241) and high $\mathrm{K} / \mathrm{Ba}$ ratios (1034-2303) with deep negative Eu anomalies indicate 

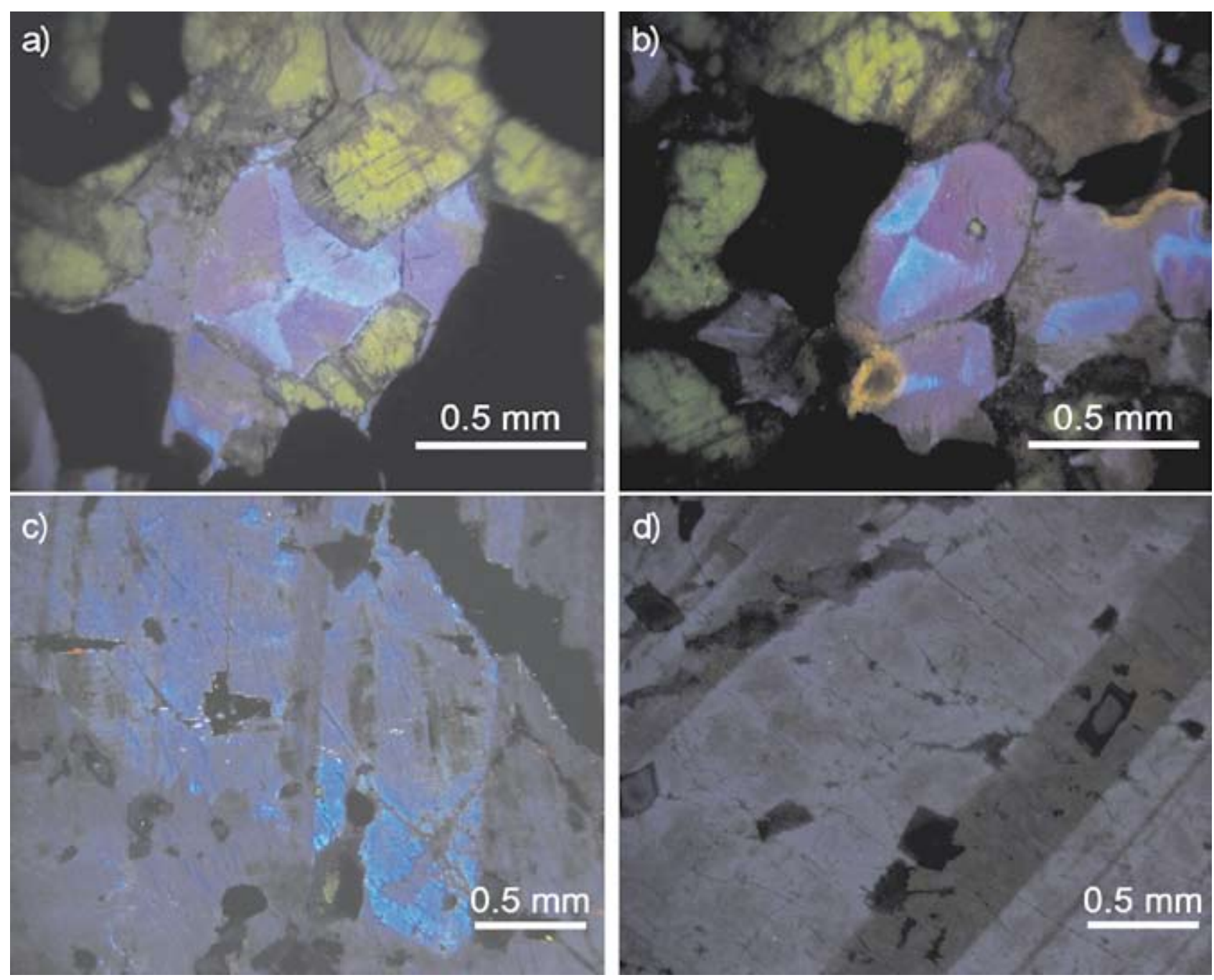

Fig. 5 Cathodoluminescence images from aplite and UST units. Aplite unit: a - Light green plagioclase rimmed by granophyric texture and surrounded by K-feldspars. a-b K-feldspar with markedly evolved sector and hourglass zoning. UST unit: c - Comb-like perthitic Kfs crystal characterized by light blue sector zoning in its central part. Jagged rims of this sector are typical. In contrast, the outer part is dark blue without zoning. Small green plagioclase crystals are present. d - Comb-like, slightly perthitic Kfs showing dark to light blue oscillatory zoning; small plagioclase laths are enclosed in Kfs megacrysts.

high degree of fractionation. Also the contents of $\mathrm{Rb}$ are 2-4 times higher than in the remaining granitoid suites of the Brno Batholith (Réna suite: 94-164 ppm, Tetčice suite: 53-104 ppm) but contents of $\mathrm{Ba}$ and $\mathrm{Sr}$ are comparably low.

Aplite unit without garnet stripes has very low concentrations of $\mathrm{Ba}(\sim 4 \mathrm{ppm})$ but slightly elevated $\mathrm{Zr}(\sim 102 \mathrm{ppm})$. Moderate concentrations of the $\mathrm{Y}(\sim 64 \mathrm{ppm}), \mathrm{REE}$ (LREE - Ce $\sim 6 \mathrm{ppm}, \mathrm{Nd} \sim 5 \mathrm{ppm}$; HREE $-\mathrm{Er} \sim 7 \mathrm{ppm}, \mathrm{Yb} \sim 10 \mathrm{ppm}), \mathrm{U}(\sim 6 \mathrm{ppm})$ and Th $(\sim 15 \mathrm{ppm})$ correlate with the low amount of garnet. Aplite unit with garnet stripes differs from the other units by slightly elevated contents of $\mathrm{K}_{2} \mathrm{O}$ (4.94 wt. \%) and $\mathrm{Fe}_{2} \mathrm{O}_{3}{ }^{\mathrm{T}}(0.93$ wt. \%), the latter present chiefly in magnetite. Contents of $\mathrm{Ba}(\sim 31 \mathrm{ppm}), \mathrm{U}(\sim 8 \mathrm{ppm})$,
Th $(\sim 18 \mathrm{ppm})$ and $\mathrm{Zr}(\sim 108 \mathrm{ppm})$ are slightly elevated as well. Very high concentrations of $\mathrm{Y}(\sim 116 \mathrm{ppm})$ are correlated with higher concentrations of LREE (Ce $\sim 9 \mathrm{ppm}, \mathrm{Nd} \sim 6 \mathrm{ppm})$ and, in particular, HREE (Er $\sim 11 \mathrm{ppm}, \mathrm{Yb} \sim 16 \mathrm{ppm})$. Coarse-grained UST unit is characterized by intermediate concentrations of $\mathrm{Ba}(17 \mathrm{ppm}), \mathrm{U}(7 \mathrm{ppm})$ and Th (13 ppm). The most distinct features are low concentrations of LREE $(\mathrm{Ce} \sim 6 \mathrm{ppm}, \mathrm{Nd} \sim 3 \mathrm{ppm})$ and HREE $(\mathrm{Er} \sim 5 \mathrm{ppm}$, $\mathrm{Yb} \sim 7 \mathrm{ppm})$ as well as low $\mathrm{Y}$ contents $(\sim 46 \mathrm{ppm})$, i.e. almost 3 times lower than in aplite unit with garnet stripes.

High alkali and $\mathrm{SiO}_{2}$ contents are consistent with a high potassic calc-alkaline series affinity (calc-alkali in$\operatorname{dex}=15.1-16.2$ ); the ASI is moderate, close to alumina 
Tab. 1 Typical whole-rock major- and trace-element analyses from the three different zones of the Hlína suite (wt. \% and ppm)

\begin{tabular}{|c|c|c|c|}
\hline Sample* & A & B & $\mathrm{C}$ \\
\hline $\mathrm{SiO}_{2}$ & 75.72 & 74.90 & 74.61 \\
\hline $\mathrm{TiO}_{2}$ & 0.03 & 0.03 & 0.03 \\
\hline $\mathrm{Al}_{2} \mathrm{O}_{3}$ & 13.60 & 14.09 & 13.83 \\
\hline $\mathrm{Fe}_{2} \mathrm{O}_{3}{ }^{\mathrm{T}}$ & 0.62 & 0.71 & 0.93 \\
\hline $\mathrm{MnO}$ & 0.12 & 0.13 & 0.32 \\
\hline $\mathrm{MgO}$ & 0.02 & 0.02 & 0.03 \\
\hline $\mathrm{CaO}$ & 0.94 & 1.11 & 1.10 \\
\hline $\mathrm{Na}_{2} \mathrm{O}$ & 4.03 & 4.21 & 3.82 \\
\hline $\mathrm{K}_{2} \mathrm{O}$ & 4.69 & 4.61 & 4.94 \\
\hline $\mathrm{P}_{2} \mathrm{O}_{5}$ & 0.02 & 0.04 & 0.05 \\
\hline LOI & 0.40 & 0.30 & 0.50 \\
\hline Sum & 100.25 & 100.22 & 100.27 \\
\hline $\mathrm{Ba}$ & 16.9 & 3.7 & 30.9 \\
\hline $\mathrm{Rb}$ & 182 & 180 & 170 \\
\hline $\mathrm{Sr}$ & 13.3 & 13.4 & 21.6 \\
\hline $\mathrm{Zr}$ & 66 & 101 & 107 \\
\hline $\mathrm{Y}$ & 45 & 64 & 116 \\
\hline $\mathrm{U}$ & 6.9 & 5.8 & 7.9 \\
\hline Th & 12.5 & 14.5 & 18.0 \\
\hline $\mathrm{Nb}$ & 28.0 & 11.2 & 12.8 \\
\hline $\mathrm{La}$ & 2.30 & 2.30 & 3.00 \\
\hline $\mathrm{Ce}$ & 5.70 & 5.90 & 8.50 \\
\hline $\operatorname{Pr}$ & 0.75 & 0.92 & 1.25 \\
\hline $\mathrm{Nd}$ & 3.40 & 4.90 & 5.90 \\
\hline $\mathrm{Sm}$ & 1.85 & 2.15 & 2.93 \\
\hline $\mathrm{Eu}$ & 0.14 & 0.17 & 0.18 \\
\hline $\mathrm{Gd}$ & 2.91 & 3.58 & 5.62 \\
\hline $\mathrm{Tb}$ & 0.76 & 0.94 & 1.66 \\
\hline Dy & 5.79 & 7.56 & 12.97 \\
\hline Но & 1.35 & 1.90 & 3.14 \\
\hline $\mathrm{Er}$ & 4.91 & 7.34 & 11.32 \\
\hline $\mathrm{Tm}$ & 1.02 & 1.47 & 2.24 \\
\hline $\mathrm{Yb}$ & 7.30 & 10.40 & 15.90 \\
\hline $\mathrm{Lu}$ & 1.35 & 1.95 & 2.75 \\
\hline ASI & 1.013 & 1.011 & 1.014 \\
\hline $\mathrm{La}_{\mathrm{N}} / \mathrm{Yb}_{\mathrm{N}}$ & 0.21 & 0.15 & 0.13 \\
\hline $\mathrm{Eu} / \mathrm{Eu}^{*}$ & 0.18 & 0.19 & 0.14 \\
\hline
\end{tabular}

* A - coarse-grained UST unit; B - fine-grained aplite unit without garnet stripes; $\mathrm{C}$ - fine-grained aplite unit with stripes of garnet.

saturation ( 1.01). Primordial mantle- (Wood et al. 1979) and chondrite-normalized (Boynton 1984) multielement plots for three different rock units (A - coarse-grained UST unit, B - aplite unit without stripes of garnet and $\mathrm{C}$ - aplite unit with garnet stripes) of the Hlína aplite- pegmatites are shown in Fig. 6. Fig. 6a represents traceelement analyses for three (A, B, C) different rock units; their concentrations are also discussed above. All three subzones are relatively depleted in LREE $(\sim 10 \times$ enrichment over chondritic abundances) relative to HREE (70-90× enrichment relative to chondrite; the $\mathrm{La}_{\mathrm{N}} / \mathrm{Yb}_{\mathrm{N}}$ ratios vary from 0.21 in UST zone to 0.13 in garnetstripes zone - Fig. 6b). The highest HREE enrichment is in garnet-stripes zone, whereas the UST zone is relatively depleted. All patterns feature a deep negative $\mathrm{Eu}$ anomaly (Eu/Eu* ranging from 0.19 in aplite zone to 0.14 in garnet-stripes zone).Tectonic discrimination diagrams (Pearce et al. 1984) suggest a WPG (Within-Plate Granites) character (Fig. 7a). Moreover, the content of $\mathrm{Y}, \mathrm{Nb}$ and $\mathrm{Ga} \times 3$ classify the Hlína suite rocks into the fields of post-collisional, post-orogenic and anorogenic A-type granites (Eby 1992; see Fig. 7b).

\subsection{Mineral assemblages and chemical composition of minerals}

Both feldspars, K-feldspar $\mathrm{Or}_{81} \mathrm{Ab}_{17} \mathrm{An}_{0.5}$ and plagioclase $\mathrm{An}_{15-8}$ (no significant differences were observed among Kfs and Plg from different units), exhibit several similar features. Very low concentrations of $\mathrm{Rb}$ and $\mathrm{Cs}$ or contents below detection limits and solely trace concentrations of $\mathrm{Pb}$ (up to 0.14 wt. \% $\mathrm{PbO}$ ), $\mathrm{Sr}$ (up to 0.08 wt. \% $\mathrm{SrO}$ ) and $\mathrm{Fe}$ (up to 0.08 wt. $\% \mathrm{Fe}_{2} \mathrm{O}_{3}$ ) were detected in $\mathrm{K}$-feldspar. Phosphorus concentrations close to the detection limit are typical of both feldspars.

Garnet is the most common mineral besides feldspars and quartz and two paragenetic, morphological, and compositional varieties were recognized in the aplite unit (Fig. 3). Nevertheless, both exhibit very similar compositional features: spessartine predominating over almandine, minor grossular component, elevated contents of HREE + Y, low concentrations of $\mathrm{P}_{2} \mathrm{O}_{5}, \mathrm{Cr}_{2} \mathrm{O}_{3}, \mathrm{ZrO}_{2}$ and $\mathrm{F}$ near or below detection limits. Small euhedral garnet grains from layered aplitic unit are slightly heterogeneous $\left(\mathrm{Sps}_{42-38} \mathrm{Alm}_{32-28} \mathrm{And}_{15-7} \mathrm{Grs}_{21-15} \operatorname{Prp}_{2-1}\right)$. This garnet is typically enriched in HREE $+\mathrm{Y}$, with up to 1.10 wt. $\% \mathrm{Y}_{2} \mathrm{O}_{3}\left(0.06\right.$ apfu), 0.53 wt. $\% \mathrm{Yb}_{2} \mathrm{O}_{3}$ and 0.20 wt. \% $\mathrm{Er}_{2} \mathrm{O}_{3}$ (Tab. 2).

Aside from garnet and magnetite, all other accessory minerals, including muscovite, are rare to extremely rare and they occur as very small grains $(1-50 \mu \mathrm{m})$. Two varieties of muscovite were recognized. Primary muscovite is evidently enriched in the ferroceladonite component with up to 3.23 apfu $\mathrm{Si}$, has low $\mathrm{Al}(2.26 \mathrm{apfu})$ and elevated $\mathrm{Fe}^{2+}{ }_{\text {tot }}(0.45$ apfu). Low contents of $\mathrm{Na}(0.03 \mathrm{apfu}), \mathrm{Mg}(0.04 \mathrm{apfu})$ and F (0.04 apfu) are typical. Secondary muscovite is close to the end-member composition. Fe-rich biotite is strongly chloritized with up to 0.46 apfu $\mathrm{K}$ and very low Ti. Secondary chlorite is Fe-rich (2.63-1.76 apfu) with $2.41-1.93$ 

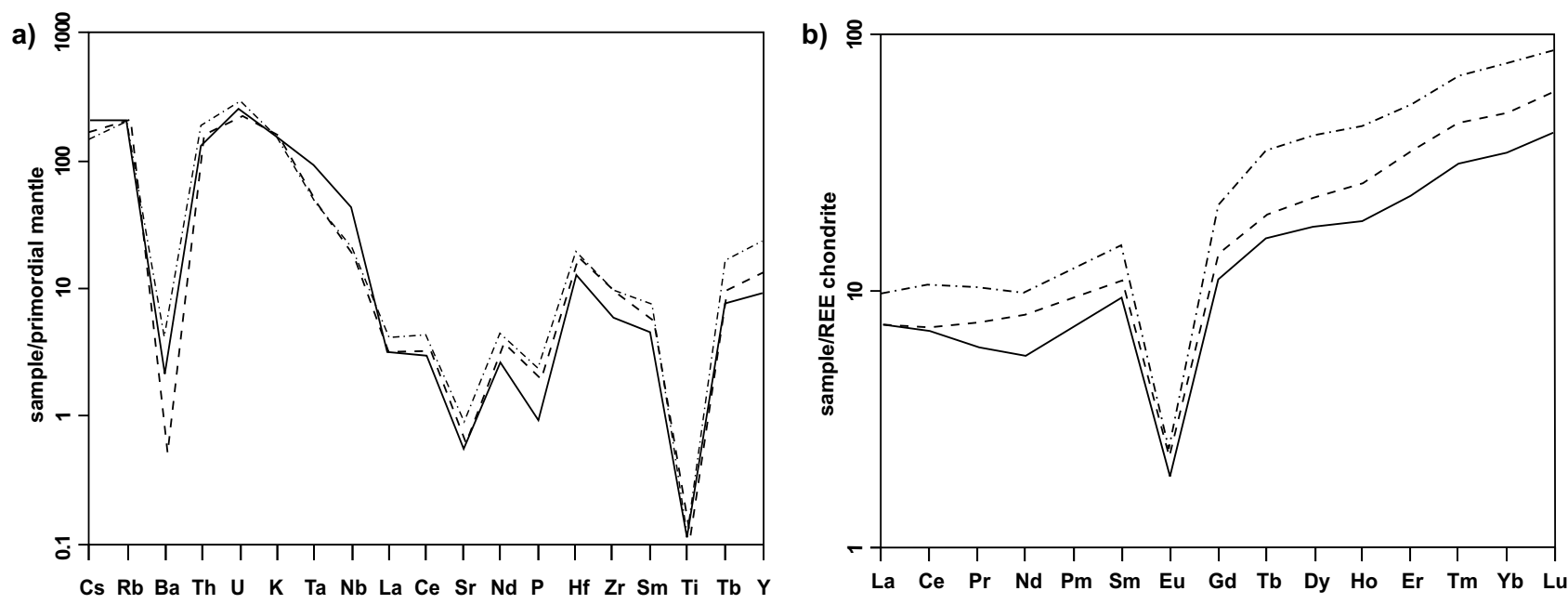

UST unit _. - . - . - a aplite unit without garnet stripes

aplite unit with garnet stripes

Fig. 6 Trace-element contents in Hlína suite. a - Primordial mantle-normalized (Wood et al. 1979) diagram of trace elements. b - Chondrite-normalized (Boynton 1984) REE patterns. The concentration of the LREE is very low, whereas HREE are unusually high (corresponding well with their contents in the garnet).

a)
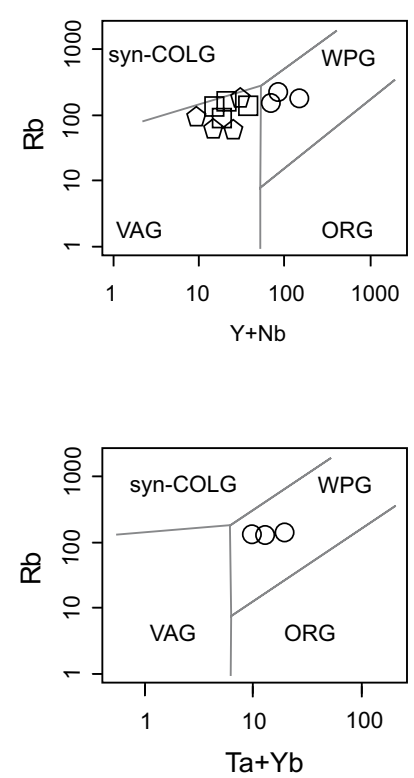
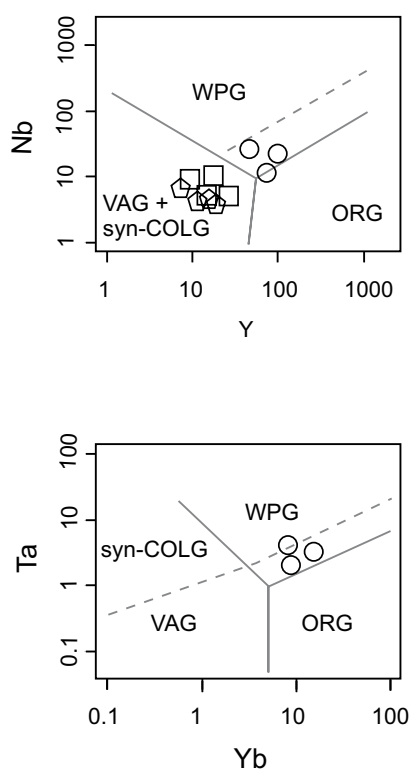

O - Hlína suite b)

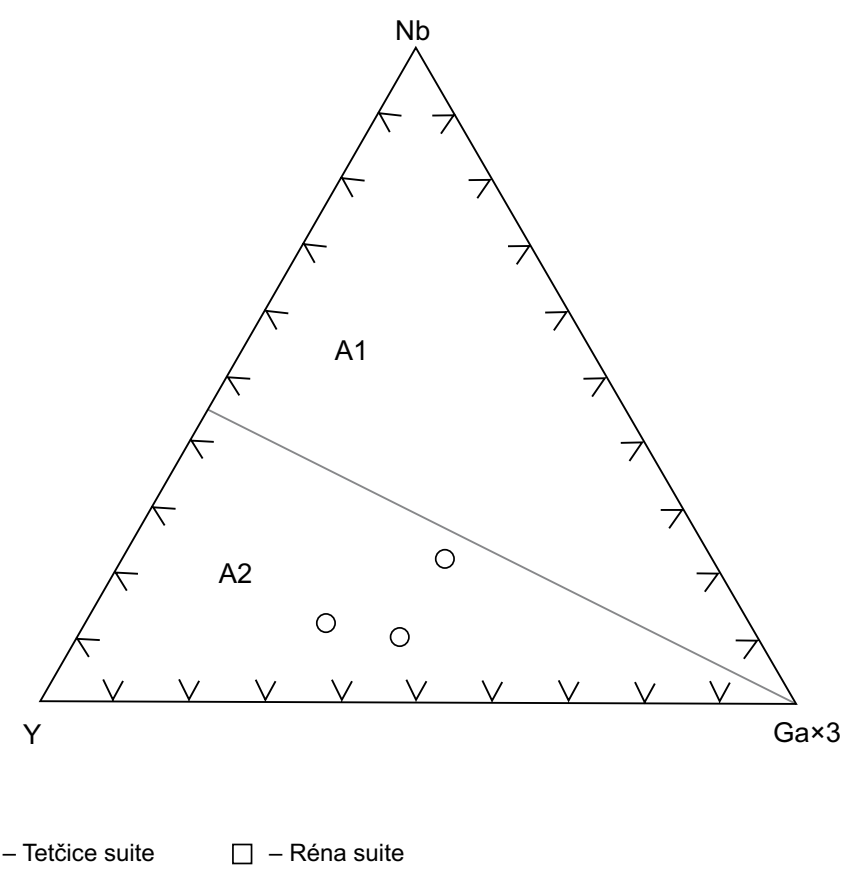

Fig. 7a $-\mathrm{The} \mathrm{Rb}-(\mathrm{Y}+\mathrm{Nb}), \mathrm{Nb}-\mathrm{Y}, \mathrm{Rb}-(\mathrm{Ta}+\mathrm{Yb})$ and $\mathrm{Ta}-\mathrm{Yb}$ diagrams for discriminating the tectonic setting of granites (Pearce et al. 1984) showing the Within Plate Granites (WPG) character of the Hlína aplite-pegmatites. VAG - Volcanic Arc Granites, ORG - Ocean Ridge Granites, syn-COLG - Syn Collisional Granites. b - Triangular Nb-Y-Ga×3 plot for classification of A-type granitoids (Eby 1992), where Hlína aplite-pegmatites fall into the A2 field (post-collisional, post-orogenic and anorogenic granites). Field A1 represents A-type granites related to hotspots, mantle plumes or continental rift zones. 

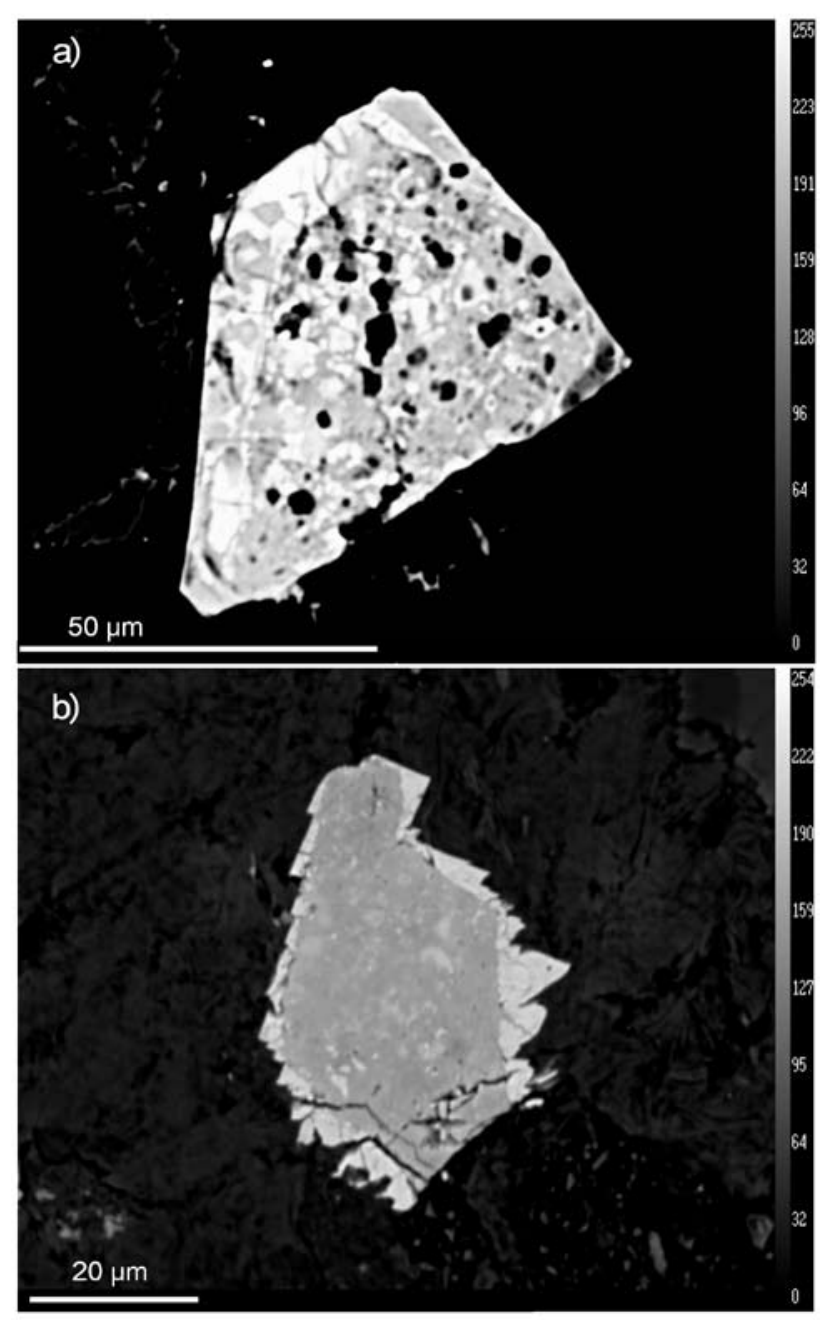

Fig. 8 Representative BSE images of zircon from fine-grained aplite unit. $\mathbf{a}-$ Common, strongly altered zircon form. b - Rare, very small $(\sim 30 \mu \mathrm{m})$ zircon overgrown by an $\mathrm{ABO}_{4}$ mineral rich in xenotime component.

apfu Si, 1.90-1.63 apfu Al, and 0.51-0.39 apfu Mg. Rare epidote-clinozoisite occurs in rims around garnet.

Zircon is commonly strongly altered and overgrown by a mineral rich in the xenotime component (Fig. 8). Very rare relics of zircon yielded only trace concentrations of $\mathrm{P}(\leq 0.01 \mathrm{apfu}), \mathrm{Y}(\leq 0.05 \mathrm{apfu}), \mathrm{U}(\leq 0.15$ wt. $\%$ $\mathrm{UO}_{2}$ ) and low $\mathrm{Zr} / \mathrm{Hf}(27.7-28.5)$ relative to late alterations and overgrowths discussed below. Very rare primary xenotime-(Y) contains, similarly to primary zircon, only trace concentrations of Si (0.04 apfu), U (0.01 apfu) and Th (0.01 apfu).

Products of alteration of primary zircon and xenotime(Y) exhibit highly variable chemical compositions related to the $\mathrm{ABO}_{4}$ general formula, including the dominant cations $-\mathrm{P}$ and/or $\mathrm{Si}$ in the B-site and $\mathrm{Y}, \mathrm{Zr}, \mathrm{Th}, \mathrm{Ca}$, and/ or $\sum \mathrm{REE}$ in the A-site (all at least locally with $>0.20$ apfu). The individual compositions are thus related to zircon, xenotime and/or cheralite. They are also mostly characterized by low totals of oxides, $\sim 80-90 \mathrm{wt} . \%$, indicating high degree of hydration. Elevated contents of Al (max. 0.13 apfu), Ca (max. 0.04 apfu), Ti (max. $0.02 \mathrm{apfu}), \mathrm{F}$ (max. $0.06 \mathrm{apfu})$ and particularly $\mathrm{Nb}$ (up to $0.06 \mathrm{apfu} ; 3.57 \mathrm{wt} . \% \mathrm{Nb}_{2} \mathrm{O}_{5}$ ) are also common in some alteration products. This extremely rare mineral close to monazite-(Nd) is often altered with the sum of oxides $\sim 90$ wt. $\%$ but still with a good stoichiometry. It is enriched in numerous elements such as $\mathrm{Si}(0.25 \mathrm{apfu})$, $\mathrm{Zr}$ (0.16 apfu), Al (0.14 apfu), Ca (0.13 apfu), Y (0.07 apfu), Fe (0.07 apfu), Th (0.06 apfu) and especially $\mathrm{Nd}$ (0.20 apfu; 13.89 wt. $\% \mathrm{Nd}_{2} \mathrm{O}_{3}$ ).

Two varieties of titanite were found. Titanite I is TaAl-rich with up to 0.21 apfu Ta (21.46 wt. \% $\left.\mathrm{Ta}_{2} \mathrm{O}_{5}\right), 0.08$ apfu $\mathrm{Nb}$ and 0.44 apfu Al. Titanite II is Al-F-rich with 0.33 apfu $\mathrm{Al}$ and 0.30 apfu $\mathrm{F}$ but low $\mathrm{Nb}$ and Ta contents. Two substitutions, $\mathrm{Al}+\mathrm{Ta}=2 \mathrm{Ti}$ and $\mathrm{AlF}=\mathrm{TiO}$, operated in these titanite varieties. Magnetite is close to the endmember composition with only traces of $\mathrm{Ti}, \mathrm{Al}$ and $\mathrm{Si}$. Ilmenite is $\mathrm{Mn}$-rich with $\mathrm{Fe} /(\mathrm{Fe}+\mathrm{Mn})=0.59-0.67$, and only trace concentrations of $\mathrm{Nb}, \mathrm{V}$ and $\mathrm{Zn}$. It is often altered to a mineral close to pseudorutile, which is slightly enriched in $\mathrm{Nb}, \mathrm{Ta}, \mathrm{Zr}$ and $\mathrm{Ca}$ but $\mathrm{Mn}$-poor.

Oxides of $\mathrm{Nb}$ and $\mathrm{Ta}$ are represented by several very rare minerals. Fersmite exhibits very low $\mathrm{Ta} /(\mathrm{Ta}+\mathrm{Nb})$ of 0.02 and only minor contents of Fe (0.16 apfu), Ti (0.07 apfu), Mn (0.04 apfu) and Y (0.03 apfu). Ferrocolumbite is slightly Ta-enriched relative to fersmite with $\mathrm{Ta} /(\mathrm{Ta}$ $+\mathrm{Nb})=0.03$ but $\mathrm{Mn}$-poor with $\mathrm{Fe} /(\mathrm{Fe}+\mathrm{Mn})=0.92$. Minor cations include Ti (0.05 apfu) and W (0.05 apfu; 3.19 wt. $\% \mathrm{WO}_{3}$ ). Minerals from pyrochlore group were also found but their structural type was not confirmed. A mineral close to plumbopyrochlore is locally strongly altered. Compositions of fresh portions ( $\sim 96 \mathrm{wt} . \% \sum$ of oxides) show high $\mathrm{Si}$ (up to $0.49 \mathrm{apfu}$ ), $\mathrm{P}<0.23 \mathrm{apfu}$, low $\mathrm{S}$ (up to $0.08 \mathrm{apfu}$ ) and very low Ta (up to $0.05 \mathrm{apfu}$, $\mathrm{Ta} /(\mathrm{Ta}+\mathrm{Nb}) \leq 0.01)$. The A site is dominated by vacancies (up to $0.63 \mathrm{apfu}$ ), but also very high contents of $\mathrm{Pb}$ (0.42 apfu), $\mathrm{Fe}^{2+}$ tot $(0.36 \mathrm{apfu}), \mathrm{Ca}$ (0.29 apfu) and U (0.17 apfu). Altered compositions ( 90 wt. $\%$ Eof oxides) are enriched in $\mathrm{Si}, \mathrm{P}$ and $\mathrm{Ca}$, but show almost equal role for vacancies in the A-site. Also a REE-Y-rich pyrochlore mineral characterized by high contents of $\mathrm{Si}, \mathrm{P}$ and $\mathrm{Pb}$ was found.

\section{Discussion}

\subsection{Geological position of aplite-pegmatite dykes}

The garnet-bearing aplite-pegmatites of the Hlína suite with locally developed UST and with evident $A$-type 
geochemical affinity strongly differ from other ( $S$ - and I-type) granitoids of the Brno Batholith in size of bodies, their internal structure, textures, geochemistry and mineralogy (see also Leichmann and Höck 2008). The mineral assemblages and chemical compositions of the individual minerals resemble the NYF pegmatite family related to $A$-type granitoids (see e.g., Černý and Ercit 2005), which is typically enriched in $\mathrm{Y}, \mathrm{Nb}, \mathrm{U}$ and $\mathrm{Th}$ but depleted in B, P, Ta and Sn. Typical NW-SE oriented aplite-pegmatite bodies cut both $S$-type granites of the Tetčice suite and chiefly $I$-type, VAG granites of the Réna suite. The NW-SE orientation of bodies is partly parallel to the Ivančice-Trboušany Fault, which separates Tetčice and Réna granitoids. Within the Tetčice suite, the strike of the aplite-pegmatite bodies correlates with NW-SE orientation of foliated metasedimentary xenoliths inside the Tetčice suite (Mittrenga et al. 1976).

Because of the lack of good field and geochronological data, it is difficult to interpret the age relations between the Hlína aplite-pegmatites and the other magmatic suites in the Brno Batholith as well as other igneous bodies that intruded the Western and Eastern granitoid complexes and the Central Basaltic Belt. Calc-alkaline basalt dykes that yielded a $\mathrm{K}-\mathrm{Ar}$ age $438 \pm 16 \mathrm{Ma}$ are the first type that cuts rhyolite and granite of the Western Granitoid Complex (Přichystal 1999). The NE-SW oriented, lamprophyric dykes occur in both Western and Eastern granite complexes and their K-Ar dates of 296-310 Ma suggest a late Variscan age (Šmejkal 1960, recalculated to new decay constants of Steiger and Jäger 1977). The last type - andesite to trachyandesite dykes - cuts Permian sediments of the Boskovice Furrow covering in part the Brno Batholith (Přichystal 1994). The origin of all mentioned subvolcanic intrusions is unknown and their emplacement and formation could be related to so far undisclosed magma bodies and/or heat source that might have caused melting of the crustal rocks and generate the intrusions.

An analogous process might be assumed for the origin of the Hlína suite granitic rocks, but none of the other intrusions are in an obvious relationship to the studied aplite-pegmatites. The Hlína suite is considered to be Cadomian in age; however, no radiometric data are available (because of strong alteration of dateable minerals) and an assessment from structural setting or field relations is not feasible. $A$-type geochemical affinity and features indicative of rapid cooling (feldspars rimmed by granophyres, well-developed sector zoning inside Kfs and UST) of the aplite-pegmatites indicate emplacement into relatively shallow-level, cold rocks. An anorogenic character of this magmatic event is reasonable; however, more detailed geochemical and isotopic data as well as radiometric dating are required to support this hypothesis.

Aplite-pegmatite bodies with Y-rich garnets arranged into stripes very similar to those from the Hlína suite were also found in the northern part of the Dyje Batholith. It is the southern equivalent of the Brno Batholith (Batík and Čtyroký 1983; Leichmann 1987), where both other granite suites (Tetčice and Réna) are also present (Finger et al. 2000a; Leichmann and Höck 2008). Hence, $A$-type granitic rocks seem to occur also in other units of the Brunovistulicum region, suggesting that $A$-type magmatism was fairly widespread although volumetrically negligible.

\subsection{Whole-rock geochemistry}

The Hlína aplite-pegmatites exhibit several characteristic geochemical features. (i) $A$-type (and/or NYF) affinity is indicated by $\mathrm{Nb}>>\mathrm{Ta}, \mathrm{Fe}>>\mathrm{Mn}, \mathrm{Fe}>>\mathrm{Mg}$, high contents of $\mathrm{Y}, \mathrm{REE}, \mathrm{Zr}, \mathrm{U}$ and $\mathrm{Th}$ in relevant accessory minerals, low $\mathrm{P}_{2} \mathrm{O}_{5}$ in feldspars and rocks and subaluminous (ASI 1.01) whole-rock signature. (ii) Low contents of volatiles such as $\mathrm{B}, \mathrm{F}, \mathrm{P}$ and probably also $\mathrm{H}_{2} \mathrm{O}$ are manifested by scarcity of volatiles-bearing minerals, in particular micas, although alterations present locally in host granodiorites indicate that some fluids (chiefly $\mathrm{H}_{2} \mathrm{O}$ ) were released from aplite-pegmatite bodies. (iii) High degree of fractionation of granitic rocks relative to other granites in the Brno Batholith is reflected in low $\mathrm{K} / \mathrm{Rb}$ (212-241) and high $\mathrm{K} / \mathrm{Ba}$ (1034-2303), very low content of $\mathrm{MgO}$ $(0.02-0.03$ wt. \%) and deep negative Eu anomaly $(\mathrm{Eu} /$ $\left.\mathrm{Eu}^{*}=0.19-0.14\right)$ (Fig. 7). The relatively high concentrations of $\mathrm{MnO}(0.12-0.32 \mathrm{wt}$. \%) and very high contents of Y (46-116 ppm) with HREE (Yb 7-16 ppm, Er 4-11 ppm) mimic their high contents in garnet (Tab. 2). It is evident that the rocks of Hlína suite with their $A$-type affinity, anhydrous character and low ASI index can hardly be derived from the host Réna and Tetčice suites. As was already discussed by Leichmann et al. (1999), the unusual character of the rocks could be the result of crystallization of an anhydrous, felsic, REE-Nb-enriched and Fe-, $\mathrm{Mg}-$, Ca-, Ti- and P-poor, highly fractionated magma, which prevented early precipitation of alkali pyroxenes and amphiboles, allanite or REE-phosphates. It enabled the survival of $\mathrm{Y}, \mathrm{REE}, \mathrm{Nb}$ and $\mathrm{Ti}$ in the melt until more evolved stages and enabled their incorporation into accessory minerals, especially garnet.

The Hlína aplite-pegmatites with obvious $A$-type affinity differ from most granitic rocks containing UST. Elsewhere such rocks occur mostly in highly fractionated, strongly peraluminous granitic systems enriched in F, P, Li, $\mathrm{H}_{2} \mathrm{O}$ and some HFSE - Sn, W, Nb and Ta, such as complex Li-rich pegmatites in Southern California (e.g., Webber et al. 1997; Morgan and London 1999; London 2008) or granite-pegmatite system from Podlesí, Erzgebirge, Czech Republic (Breiter 2002; Breiter et al. 2005). The only granitic rocks with potential $A$-type affinity and abundant UST comparable to the Hlína suite 
Tab. 2 Representative electron-microprobe analyses of garnet (wt. \% and apfu)

\begin{tabular}{|c|c|c|c|c|c|c|c|c|c|c|c|}
\hline \multirow[b]{2}{*}{ Sample } & \multicolumn{7}{|c|}{ Grt from lines and stripes } & \multicolumn{4}{|c|}{ Grt phenocrysts } \\
\hline & 20 & 21 & 22 & 23 & 24 & 25 & 26 & 10 & 11 & 12 & 13 \\
\hline $\mathrm{SiO}_{2}$ & 35.06 & 35.64 & 35.37 & 35.66 & 35.38 & 35.75 & 35.77 & 35.11 & 35.18 & 35.57 & 35.73 \\
\hline $\mathrm{TiO}_{2}$ & 0.46 & 0.36 & 0.39 & 0.36 & 0.37 & 0.24 & 0.21 & 0.41 & 0.03 & 0.26 & 0.26 \\
\hline $\mathrm{Al}_{2} \mathrm{O}_{3}$ & 16.80 & 17.27 & 17.02 & 17.56 & 17.22 & 18.5 & 18.38 & 16.97 & 19.00 & 18.58 & 18.62 \\
\hline $\mathrm{Fe}_{2} \mathrm{O}_{3}$ & 5.48 & 5.16 & 5.35 & 5.22 & 5.25 & 4.95 & 4.12 & 5.38 & 4.35 & 4.75 & 4.47 \\
\hline $\mathrm{Yb}_{2} \mathrm{O}_{3}$ & 0.62 & 0.15 & 0.42 & 0.21 & 0.28 & 0.16 & 0.25 & 0.77 & 0.66 & 0.22 & 0.09 \\
\hline $\mathrm{Er}_{2} \mathrm{O}_{3}$ & n.d. & n.d. & n.d. & n.d. & n.d. & n.d. & n.d. & 0.32 & 0.16 & n.d. & n.d. \\
\hline $\mathrm{FeO}$ & 11.91 & 12.44 & 12.26 & 12.38 & 12.23 & 13.58 & 14.82 & 14.51 & 15.22 & 14.46 & 14.32 \\
\hline $\mathrm{MnO}$ & 19.24 & 19.58 & 19.14 & 19.61 & 19.36 & 19.53 & 19.18 & 18.70 & 19.81 & 19.98 & 19.47 \\
\hline $\mathrm{MgO}$ & 0.39 & 0.31 & 0.38 & 0.29 & 0.34 & 0.31 & 0.41 & 0.67 & 0.44 & 0.39 & 0.33 \\
\hline $\mathrm{Na}_{2} \mathrm{O}$ & 0.08 & 0.07 & 0.07 & 0.08 & 0.06 & 0.06 & 0.09 & 0.07 & 0.14 & 0.08 & 0.09 \\
\hline Total & 99.57 & 99.85 & 99.75 & 100.05 & 99.59 & 100.49 & 100.03 & 100.23 & 100.15 & 100.62 & 100.20 \\
\hline $\mathrm{Si}^{4+}$ & 2.930 & 2.951 & 2.941 & 2.943 & 2.941 & 2.930 & 2.950 & 2.929 & 2.915 & 2.922 & 2.936 \\
\hline $\mathrm{Ti}^{4+}$ & 0.029 & 0.022 & 0.024 & 0.022 & 0.023 & 0.015 & 0.013 & 0.026 & 0.002 & 0.016 & 0.016 \\
\hline $\mathrm{Al}^{3+}$ & 1.654 & 1.685 & 1.668 & 1.708 & 1.687 & 1.787 & 1.787 & 1.668 & 1.855 & 1.799 & 1.803 \\
\hline $\mathrm{Fe}^{3+}$ & 0.345 & 0.322 & 0.335 & 0.324 & 0.328 & 0.305 & 0.256 & 0.337 & 0.271 & 0.294 & 0.277 \\
\hline $\mathrm{Y}^{3+}$ & 0.081 & 0.054 & 0.068 & 0.044 & 0.060 & 0.024 & 0.040 & 0.069 & 0.042 & 0.038 & 0.028 \\
\hline $\mathrm{Yb}^{3+}$ & 0.016 & 0.004 & 0.011 & 0.005 & 0.007 & 0.004 & 0.006 & 0.020 & 0.017 & 0.006 & 0.002 \\
\hline $\mathrm{Er}^{3+}$ & n.d. & n.d. & n.d. & n.d. & n.d. & n.d. & n.d. & 0.008 & 0.004 & n.d. & n.d. \\
\hline $\mathrm{Fe}^{2+}$ & 0.832 & 0.862 & 0.853 & 0.854 & 0.850 & 0.930 & 1.022 & 1.012 & 1.054 & 0.993 & 0.984 \\
\hline $\mathrm{Mn}^{2+}$ & 1.362 & 1.373 & 1.348 & 1.371 & 1.363 & 1.356 & 1.340 & 1.321 & 1.390 & 1.390 & 1.355 \\
\hline $\mathrm{Ca}^{2+}$ & 0.690 & 0.678 & 0.695 & 0.679 & 0.689 & 0.601 & 0.522 & 0.515 & 0.373 & 0.482 & 0.544 \\
\hline $\mathrm{Na}^{+}$ & 0.013 & 0.011 & 0.011 & 0.013 & 0.010 & 0.010 & 0.014 & 0.011 & 0.022 & 0.013 & 0.014 \\
\hline $\mathrm{Sps}^{*}$ & 39.5 & 40.0 & 39.2 & 40.1 & 39.7 & 40.1 & 40.4 & 38.4 & 42.4 & 41.5 & 40.6 \\
\hline Alm & 24.2 & 25.3 & 25.1 & 25.1 & 24.9 & 27.5 & 31.0 & 29.6 & 32.1 & 29.9 & 29.5 \\
\hline Grs & 20.0 & 19.7 & 20.2 & 19.8 & 20.1 & 17.8 & 15.8 & 15.0 & 11.4 & 14.4 & 16.3 \\
\hline Adr & 14.9 & 13.8 & 14.2 & 14.0 & 14.1 & 13.5 & 11.3 & 14.6 & 12.5 & 12.8 & 12.4 \\
\hline Prp & 1.4 & 1.1 & 1.4 & 1.0 & 1.2 & 1.1 & 1.5 & 2.4 & 1.7 & 1.4 & 1.2 \\
\hline
\end{tabular}

Garnet formulae were calculated based on $\sum$ cations $=8$ and 120

*Garnet end-members in mole \%

n.d. - not determined.

are the porphyritic granite intrusions at the Henderson Mine, Empire, Colorado (Shannon et al. 1982). However, mineral compositions in the Henderson Mine, including the assemblage molybdenite + quartz \pm fluorite \pm pyrite \pm wolframite \pm cassiterite \pm topaz, suggest high activity of $\mathrm{F}$ and other volatiles $\left(\mathrm{S}, \mathrm{H}_{2} \mathrm{O}\right)$.

\subsection{Origin of UST and garnet layering worldwide}

Several models explaining magmatic layering (see overview in Morgan and London 1999; London 2008) were published in the last decades, but problems with the genetic interpretations of the layered textures persist. The first hypothesis invoking segregation and crystallization at supersaturated boundary was published by Jahns and Tuttle (1963). Gravitational crystal-settling model - used for explanation of the layering in the mafic magmatic rock (Parsons 1987) - seems problematic in granitic systems because of the higher magma viscosity and the smaller density difference between crystals and the acid melt.

In addition, Hort et al. (1993) considered the role of oscillatory nucleation in the origin of layered- and cumulate-like textures, associated with convection within the melt. In their model, continued growth eventually leads 
to gravitational settling of layered textures on the floor of the intrusion body. Nevertheless, Hort et al. (1993) concluded that layered cumulate-like structures can be generated by such a mechanism only in thick bodies (over $\sim 100 \mathrm{~m}$ ) where the degree of undercooling is much lower relative to thin dykes.

The scenarios based on undercooling and rapid, multistage, non-equilibrium crystallization from $\mathrm{H}_{2} \mathrm{O}$ saturated melt currently dominate (see e.g., McBirney 1987; London 1992; Webber et al. 1997, 1999; Morgan and London 1999; Balashov 2000; Breiter et al. 2005). London (1992) suggested that repetitive layers in aplitepegmatite originated in the system far from crystal-melt equilibrium. This is well documented by different textures and chemical composition of the individual layers. The emplacement environment of these layered bodies is also relevant as is their common volatile over/supersaturation during crystal nucleation and growth (see also Morgan and London 1999). According to Fenn (1977) and London (1992), nucleation rate of quartz and plagioclase at the same degree of undercooling (and in the same crystallizing zones) was much higher than that of K-feldspar, which enabled growth of large K-feldspar crystals associated with small plagioclase and quartz grains. Authors such as Vernon (1986) and Cox et al. (1996) proposed that formation of large K-feldspar crystals can be explained by lower nucleation rate in a water-rich melt. Not only melt saturation by volatiles is important for UST formation; also rapid and repeated undercooling of the system seems relevant (Webber et al. 1997). According to Rockhold et al. (1987) and newly to London (1999, 2008), the boundary-layer model can provide an initial step for evolution of layered textures.

Webber et al. (1999) constructed conductive cooling models of four aplite-pegmatite dykes with layered textures in the Southern California. Rapid cooling may have resulted in relatively rapid nucleation and growth of albite, K-feldspar, quartz and facilitated development of UST zones. Development of the chemical boundary layers of excluded components (initially $\mathrm{Mn}$ and $\mathrm{Fe}$ ) ahead of the crystallization front may have lead to $\mathrm{Mn}$ and Fe accumulation to the critical point of local saturation and thus set up the proper conditions for starting garnet crystallization. Repetition of garnet-rich zones can be explained by oscillatory crystallization at the chemical boundary front where the saturation of essential elements repeatedly occurred.

Bogoch et al. (1997) suggested that stripes of garnet could result from hydrofracturing of the partially crystallized magma by volatiles (especially by $\mathrm{H}_{2} \mathrm{O}$ vapor) followed by garnet crystallization. However, it is probable that $\mathrm{H}_{2} \mathrm{O}$-enriched minerals such as micas would have to crystallize along the ruptures.
The last hypothesis - "swinging eutectic" (Balashov et al. 2000) - may satisfactorily explain the presence of repetitive UST zones in layered aplite-pegmatite dykes. The authors suggested that abrupt adiabatic drop in pressure caused by opening of the system (e.g. by sudden escape of fluids) during crystallization may also lead to undercooling and formation of the UST zones. Subsequent pressure increase restored normal (fine-grained) crystallization of granite. Fluid pressure oscillation due to episodic degassing is also important in this model.

\subsection{Origin of Hlína suite's UST and garnet layering}

Because of the similar, and rather limited, thicknesses of the layered aplite-pegmatites studied by Webber et al. (1999) and the Hlína dykes (from $2 \mathrm{~m}$ to $50 \mathrm{~m}$ ), the gravitational settling or melt convection models are not appropriate for the studied rocks. Likewise, the garnet layering was not probably related to hydrofracturing due to the assumed anhydrous and volatile-poor nature of the melt parental to the Hlína aplite-pegmatites.

The aplite-pegmatite bodies of the Hlína suite are commonly zoned showing alternating fine-grained garnetbearing aplite zones alternating with coarse-grained comb-like UST zones (and coarse-grained pegmatite unit with random orientation of crystals at other localities). A different modal composition and a textural dissimilarity between the UST and the aplite zones is the main noticeable feature of the studied layered intrusions. The interlayered aplite zones show effects of very rapid cooling: the hour-glass sector zoning in K-feldspars as well as abundant symplectites-granophyres developed between feldspars and quartz grains. This is in contrast to probably slightly slower crystallization of the coarse-grained UST zones because the CL imaging showed oscillatory zoning of comb-like K-feldspar crystals. Both sector zoning and oscillatory zoning in K-feldspars also imply that complete equilibrium was not reached during crystallization of either the aplite or the UST zones.

Small zoned plagioclase laths are enclosed in comblike K-feldspar megacrysts (see e.g., Shelley 1992). Based on previous discussion, it is probable that the crystallization of magma was probably repeatedly disrupted (producing the alternating UST and interlayered aplite units) and there is abundant textural evidence for rapid crystal growth of both aplite and pegmatite zones.

Furthermore, the process of non-equilibrium crystallization is indicated by the rhythmically layered (striped) structure of the magmatic Y-rich garnet (spessartinealmandine solution) with oscillatory and sector zoning. These stripes are exclusively present in the fine-grained aplitic zones. This type of well-developed rhythmic layering of alternating garnet-rich and garnet-poor layers is 
texturally similar to that observed in the George Ashley Block, Pala Pegmatite District, Southern California (Webber et al. 1997). However, strongly peraluminous character of the Californian garnet-rich aplite zones represents a major difference from the Hlína suite. The zoning (Mnrich cores, Fe-rich rims) of garnet grains is identical to that described by Macleod (1992). Hence, the magnetic properties of garnet may have controlled its arrangement into the stripes. However, the associated magnetite does not show any linear/planar alignment. Taken together, the most likely mechanism for formation of the garnet-rich layers at Hlína is considered oscillatory crystallizationrelated process at the locally evolving chemical boundary front. According to textural relationships in the rock, this boundary front was probably formed next to the partly solidified surface of the UST unit.

\section{Conclusions and summary}

Layered, garnet-bearing, aplite-pegmatite dykes of the Hlína granitic suite cropping out in the southwestern part of the Brno Batholith are characterized by two alternating units: (i) a coarse-grained pegmatite unit showing comb-like UST and (ii) a fine-grained aplite unit. The third observed but not presently studied unit, coarse-grained pegmatite lacking any UST and layering, is not present at the examined locality but is more abundant at other outcrops of this region.

The subaluminous Hlína suite has an $A$-type (and/or NYF) affinity, which is indicated by elevated concentrations of Y, REE (especially HREE), Zr, Nb, Ta, U and Th. Low contents of volatiles (B, F, P and also $\mathrm{H}_{2} \mathrm{O}$ ) are noticeable. All these features are strikingly different from other known UST-bearing intrusions worldwide, which are typically associated with strongly peraluminous, volatile-rich (B, F, $\mathrm{P}$ and $\mathrm{H}_{2} \mathrm{O}$ ) intrusions of distinct mineralogy. Magmatic layering of garnet (garnets lined up into stripes inside aplite unit) is explained by formation of boundary chemical layers at the surface of the coarse-grained UST unit.

Acknowledgements. The authors are very grateful to the reviewers K. Breiter and A. Dini, and the Guest Editor P. Nabelek for constructive criticism that significantly improved the manuscript. The authors thank R. Škoda and P. Gadas (Department of Geological Sciences, Masaryk University, Brno) for technical assistance. This work was supported by the research projects GAČR IAA300130801 and MSM0021622412 to JL and MN.

\section{References}

Balashov VN, Zaraisky GP, Setlmann R (2000) Fluidmagma interaction and oscillatory phenomena during crystallization of granitic melt by accumulation and escape of water and fluorine. Petrology 8: 505-524

BATíK P, ČTYROKÝ P (1983) Explanations to the geological map 1: 25000 sheet Šatov 34-131. Czech Geological Survey, Prague, pp 1-62 (in Czech)

Bogoch R, Bourne J, Shirav M, Harnois L (1997) Petrochemistry of a Late Precambrian garnetiferous granite, pegmatite and aplite, Southern Israel. Mineral Mag 61: 111-122

Boynton WV (1984) Cosmochemistry of the rare earth elements: meteorite studies. In: Henderson PE (ed) Rare Earth Element Geochemistry. Developments in Geochemistry. Elsevier, Amsterdam, pp 63-114

BREITER K (2002) From explosive breccia to unidirectional solidification textures: magmatic evolution of a phosphorus and fluorine-rich granite system (Podlesí, Krušné Hory Mts., Czech Republic). Bull Czech Geol Survey 77: 67-92

Breiter K, Müller A, Leichmann J, Gabašová A (2005) Textural and chemical evolution of a fractionated granitic system: the Podlesí stock, Czech Republic. Lithos 80: $323-345$

Cox RA, Dempster TJ, Bell BR, Rogers G (1996) Crystallization of the Shap granite: evidence from zoned K-feldspar megacrysts. J Geol Soc, London 153: 625-635

ČERNÝ P, ERCIT TS (2005) The classification of granitic pegmatites revised. Canad Mineral 43: 2005-2026

Dallmeyer DR, Fritz H, Neubauer F, Urban M (1994) ${ }^{40} \mathrm{Ar} /{ }^{39} \mathrm{Ar}$ mineral age controls on the tectonic evolution of the southeastern Bohemian Massif. Pre-alpine Crust in Austria, Excursion guide 'Geology of the Moravian Zone', Krems, pp 14-22

Dudek A (1980) The crystalline basement block of the Outer Carpathians in Moravia: Brunovistulicum. Rozpr Čs Akad Věd, Ř mat prír Věd 90: 3-85

Duke EF, Papike JJ, Laul JC (1992): Geochemistry of a boron rich peraluminous granite pluton: the Calamity Peak layered granite-pegmatite complex, Black Hills, South Dakota. Canad Mineral 30: 811-833

Eвy GN (1992) The A-type granitoids: a review of their occurrence and chemical characteristics and speculations on their petrogenesis. Lithos 26: 115-134

FENN PM (1977) The nucleation and growth of alkali feldspars from hydrous melt. Canad Mineral 15: 135-161

Finger F, HanžL P, Pin C, von Quadt A, Steyrer HP (2000a) The Brunovistulicum: Avalonian Precambrian sequence at the eastern end of the Variscides. In: Franke W, Altherr R, HaAk W, Oncken O, Tanner D (eds) Orogenic Processes: Quantification and Modelling in the Variscan Belt of Central Europe. Geological Society London Special Publications 179: 103-112

Fritz H, Dallmeyer R, Neubauer F (1996) Thick-skinned versus thin-skinned thrusting: rheology controlled thrust propagation in the Variscan collisional belt (the south- 
eastern Bohemian Massif, Czech Republic-Austria). Tectonics 15: 1389-1413

HANŽL P (1994) The correlation between the Nectava gneisses and granodiorites of the northern part of the Brno Massif. Bull Czech Geol Survey 69: 73-80

HANŽL P, Melichar R (1997) Brno Massif: a section through the active continental margin or composed terrane? Krystalinikum 23: 33-58

Hort M, Marsh BD, Spohn T (1993) Igneous layering through oscillatory nucleation and crystal settling in wellmixed magmas. Contrib Mineral Petrol 114: 425-440

JahnS RH, TutTle FO (1963) Layered pegmatite-aplite intrusives. Mineralogical Society of America, Special Papers 1: pp 78-92

JeLíneK E, Dudek A (1993) Geochemistry of subsurface Precambrian plutonic rocks from the Brunovistulian Complex in the Bohemian Massif, Czechoslovakia. Precambr Res 62: 103-125

Kormilitsyn VS, Manuilova MM (1957) Rhythmic banded quartz porphyry, Bugdai Mountain, southeast Transbaykal region. Zapiski Vsesoyouz Mineral Obsch 86: 355-364 (in Russian)

Leichmann J (1987) Petrology of the western part of the Dyje Massif. Unpublished MSci. thesis, University of J. E. Purkyně, Brno, pp 1-66 (in Czech)

Leichmann J (1994) Trondhjemites of the Brno Massif. Geol výzk Mor a Slez v r 1993: 82-85 (in Czech)

Leichmann J (1996) Geologie und Petrologie des Brünner Massivs. Unpublished PhD. thesis, University of Salzburg, pp 1-118

LeichmanN J, Höck V (2008) The Brno Batholith: an insight into the magmatic and metamorphic evolution of the Cadomian Brunovistulian Unit, eastern margin of the Bohemian Massif. J Geosci 53: 218-305

Leichmann J, Novák M, Sulovský P (1999) Peraluminous whole-rock chemistry versus peralkaline mineralogy of highly fractionated, garnet-bearing granites from the Brno Batholith. Ber Deutsch Miner Ges 1: 144

LONDON D (1992) The application of experimental petrology to the genesis and crystallization of granitic pegmatites. Canad Mineral 30: 499-540

LoNDON D (1999) Melt boundary-layers and the growth of pegmatitic textures. Canad Mineral 37: 826-827

London D (2008) Pegmatites. Canad Mineral, Special Publications 10: pp 1-347

MACLEOD G (1992) Zoned manganiferous garnet of magmatic origin from the Southern Uplands of Scotland. Mineral Mag 56: 115-116

MARShall DJ (1988) Cathodoluminescence of Geological Materials. Unwin Hyman, London, pp 1-146

McBirney AR (1987) Constitutional zone refining of layered mafic intrusions. In: PARSONS I (ed) Origin of Igneous Layering. D. Reidel Publishing, Dordrecht, pp $437-452$
Mittrenga P, Rejl L (1993) Brno Massif. In: Přichystal A, Obstová V, Suk M (eds) Geology of Moravia and Silesia. Moravian museum, Brno, pp 1-168

Mittrenga P, Weiss J, Rejl L (1976) New results on the geological structure of the southern part of the Brno Massif. Výzk Práce Ústř Úst Geol 13: 33-39 (in Czech)

Morgan GB, London VI (1999) Crystallization of the Little Three layered pegmatite-aplite dike, Ramona District, California. Contrib Mineral Petrol 136: 310-330

Pearce JA, Harris NBW, Tindle AG (1984) Trace element discrimination diagrams for the tectonic interpretation of the granitic rocks. J Petrol 25: 956-983

Parsons I (1987) Origins of Igneous Layering. Kluwer Academic Publishers. NATO Science Series: C: Mathematical \& Physical Sciences 196: pp 1-696

Pouchou JL, Pichoir F (1985) "PAP" $(\varphi-\rho-Z)$ procedure for improved quantitative microanalysis. In: ARMSTRONG JT (ed) Microbeam Analysis. San Francisco Press, San Francisco, pp 104-106

PŘIICHYSTAL A (1994) A lamprophyric dyke in basal Devonian clastics at Tasovice near Znojmo (the Dyje Massif). Geol Výzk Mor Slez v r 1993: 59-60 (in Czech)

PřI ICHYSTAL A (1999) K-Ar age determination of a basaltic dyke from Želešice (Brno Massif). Geol Výzk Mor Slez v r 1999: 60-62 (in Czech)

Rockhold JR, Nabelek PI, Glascock MD (1987) Origin of rhythmic layering in the Calamity Peak satellite pluton of the Harney Peak granite, South Dakota: the role of boron. Geochim Cosmochim Acta 51: 487-496

Shannon JR, Walker BM, Carten RB, Geraghty EP (1982) Unidirectional solidification textures and their significance in determining relative ages of intrusions at the Henderson Mine, Colorado. Geology 10: 293-297

ShelLey D (1992) Igneous and Metamorphic Rocks Under the Microscope: Classification, Textures, Microstructures and Mineral Preferred Orientation. Chapman and Hall, London, pp 211-244

SkÁCelová D, Weiss J (1978) A model of the development of the Brno Massif based on geophysical data. Čas Mineral Geol 23: 409-415 (in Czech)

Steiger RH, JÄGER E (1977) Subcommission on Geochronology; convention on the use of decay constants in geo- and cosmochronology. Earth Planet Sci Lett 36: 359-362

ŠMEJKAL V (1960) The absolute age of some igneous and metamorphic rocks determined using $\mathrm{K}-\mathrm{Ar}$ method. Věst ÚÚG 35: 441-449 (in Czech)

STANĚK J (1982) Minerals of the Brno Massif. In: ŠTELCL J (ed) Sborník prŕspěvků Konference Brno a geologie, Brno, pp 182-185 (in Czech)

Štelcl J, Weiss J (eds) (1986) The Brno Massif. University of J. E. Purkyně, Brno, pp 1-255 (in Czech)

van Breemen O, Aftalion M, Bowes D, Dudek A, Mísař Z, Povondra P, VRÁnA S (1982) Geochronological studies of the Bohemian Massif, Czechoslovakia, and their 
significance in the evolution of Central Europe. Trans Roy Soc Edinb, Earth Sci 73: 89-108

VERNON RH (1986) K-feldspar megacrysts in granites - phenocrysts, not porphyroblasts. Earth Sci Rev 23: 1-63

Webber KL, Falster AU, Simmons WB, Foord EE (1997) The role of diffusion-controlled oscillatory nucleation in the formation of line rock in pegmatite-aplite dikes. J Petrol 38: 1777-1791

Webber KL, Simmons WB, Falster AU, Foord EE (1999) Cooling rates and crystallization dynamics of shallow level pegmatite-aplite dikes, San Diego County, California. Amer Miner 84: 708-717
Wood DA, Joron JL, Treuil M (1979) A re-appraisal of the use of trace elements to classify and discriminate between magma series erupted in different tectonic settings. Earth Planet Sci Lett 45: 326-336

Zaraisky GP, Setlmann R, Shatov VV, Aksyuk AM, Shapovalov YuB, Chevychelov VYu (1997) Petrography and geochemistry of Li-F granites and pegmatite aplite banded rocks from the Orlovka and Etyka tantalum deposits in Eastern Transbaikalia, Russia. In: PAPunen H (ed) Mineral Deposits. Balkema, Rotterdam, pp 695-698 